\title{
24. PALEOGENE AND EARLY NEOGENE PLANKTONIC FORAMINIFER BIOSTRATIGRAPHY OF SITES 738 AND 744, KERGUELEN PLATEAU (SOUTHERN INDIAN OCEAN) ${ }^{1}$
}

\author{
Brian T. Huber ${ }^{2}$
}

\begin{abstract}
A virtually complete composite history of Cenozoic pelagic sedimentation was recovered from ODP Sites 738 $\left(62^{\circ} 43^{\prime} \mathrm{S}\right)$ and $744\left(61^{\circ} 35^{\prime} \mathrm{S}\right)$, drilled during Leg 119 on the Kerguelen Plateau. An excellent magnetobiochronologic record was obtained from upper Eocene through Holocene sediments at Site 744, and an expanded lower Paleocene through lower Oligocene sequence was cored at Hole 738. Analysis of the stratigraphic distribution of over 125 planktonic foraminifer taxa from these sites reveals changes in species composition that were strongly influenced by the climatic evolution of Antarctic water masses.

Early Paleocene planktonic foraminifer assemblages are nearly identical in species composition to coeval assemblages from low and middle latitude sites, showing the same patterns of post-extinction recovery and taxonomic radiation. Biogeographic isolation, revealed by the absence of tropical keeled species, became apparent by late early Paleocene time. Diversity increased near the Paleocene/Eocene boundary when keeled morozovellids immigrated to the Kerguelen Plateau. Greatest diversity ( 23 species) was achieved by early Eocene time, corresponding to a Cenozoic warming maximum that has been recognized in lower Eocene deep sea and terrestrial sediments worldwide. A gradual decline in diversity from the late early through middle Eocene, primarily due to the disappearance of acarininids, parallels the record of cooling paleotemperatures in Southern Ocean surface waters. Chiloguembelina-dominated assemblages appeared in the late middle Eocene and persisted through the early Oligocene as Antarctic surface waters became thermally isolated.

Late Eocene and early Oligocene assemblages exhibit considerably lower diversity than the older Eocene faunas, and were dominated by chiloguembelinids, subbotinids, and catapsydracids during a time of pronounced climatic cooling and development of continental glaciation on East Antarctica. The small foraminifer Globigerinita juvenilis replaced chiloguembelinids as the dominant taxon during the late Oligocene. Diversity increased slightly toward the end of the late Oligocene with new appearances of several tenuitellid, globoturborotalitid, and globigerinid species. The trend toward diminishing planktonic foraminifer diversity was renewed during the late early Miocene as siliceous productivity increased in the Antarctic surface waters, culminating with the reduction to nearly monospecific assemblages of Neogloboquadrina pachyderma that occur in Pliocene-Holocene biosiliceous sediments.

An Antarctic Paleogene zonal scheme previously devised for ODP Sites 689 and 690 in the Weddell Sea is used to biostratigraphically subdivide the Kerguelen Plateau sequence. The definition of one Antarctic Paleogene biozone is modified in the present study to facilitate correlation within the southern high latitudes. The ages of 13 late Eoceneearly Miocene datum events are calibrated based on a magnetobiochronologic age model developed for Site 744 .
\end{abstract}

\section{INTRODUCTION}

The southern Kerguelen Plateau is located in the Indian Ocean between $57^{\circ} \mathrm{S}$ and $64^{\circ} \mathrm{S}$, south of the present-day Polar Front and north of the Antarctic Divergence. It lies in water depths generally between 1500 and $2000 \mathrm{~m}$ and stands about $2-3 \mathrm{~km}$ above the adjacent ocean basins. It is bounded by the Australian-Antarctic Basin to the northeast, Crozet Basin to the northwest, and the African-Antarctic Basin to the southwest. Terrigenous sediment is minimal on the plateau because of a narrow trough about $3500 \mathrm{~m}$ deep that separates the Kerguelen Plateau from the Antarctic continental margin.

Eleven sites were drilled on the Kerguelen Plateau (Sites 736738, 744-746) and in Prydz Bay, Antarctica (Sites 739-743), during Ocean Drilling Program (ODP) Leg 119 (Fig. 1). The principle paleoceanographic objective for drilling Sites 738 and 744 on the southern Kerguelen Plateau was to document changes in the Late Cretaceous and Cenozoic climate of East Antarctica (Barron, Larsen, et al., 1989). Because of the proximity of the southern Kerguelen Plateau sites to Antarctica, sediments cored

\footnotetext{
' Barron, J., Larsen, B., et al., 1991. Proc. ODP, Sci. Results, 119: College Station, TX (Ocean Drilling Program).

2 Department of Paleobiology, NHB-121, National Museum of Natural History, Smithsonian Institution, Washington, DC 20560, U.S.A.
}

in this region record the initial northward expansion of Antarctic water masses and their subsequent latitudinal fluctuations.

This paper documents Cenozoic planktonic foraminifer distributions at Sites 738 and 744 , and establishes a foraminifer biostratigraphy for the recovered sections. Discussion of Maestrichtian through early Danian planktonic foraminifer distributions and the Cretaceous/Tertiary boundary at Hole $738 \mathrm{C}$ is provided in a companion paper by Huber (this volume).

The principle biostratigraphic scheme used in this study was developed by Stott and Kennett (1990) for Antarctic Paleogene sediments drilled at ODP Sites 689 and 690 on the Maud Rise (Weddell Sea). The Kerguelen Plateau fauna strongly resembles the Maud Rise assemblages, and the order of first and last occurrences of selected species are also similar. Although some planktonic foraminifer zones previously defined for the southern temperate regions of the southwest Pacific and New Zealand (i.e., Jenkins, 1966, 1971) can be recognized at the Kerguelen Plateau, several cannot be distinguished because of the rarity or sporadic occurrences of the defining taxa. Cenozoic zonations developed for lower latitude regions (e.g., Berggren, 1969; Blow, 1969, 1979; Berggren and Miller, 1988) are of little use in the subpolar-polar region owing to the absence of most zonal marker taxa.

\section{METHOD OF STUDY}

This study is based on observations of all Hole 744A and Site 738 core catchers, and samples $\left(20 \mathrm{~cm}^{3}\right)$ taken at $1.5 \mathrm{~m}$ in- 


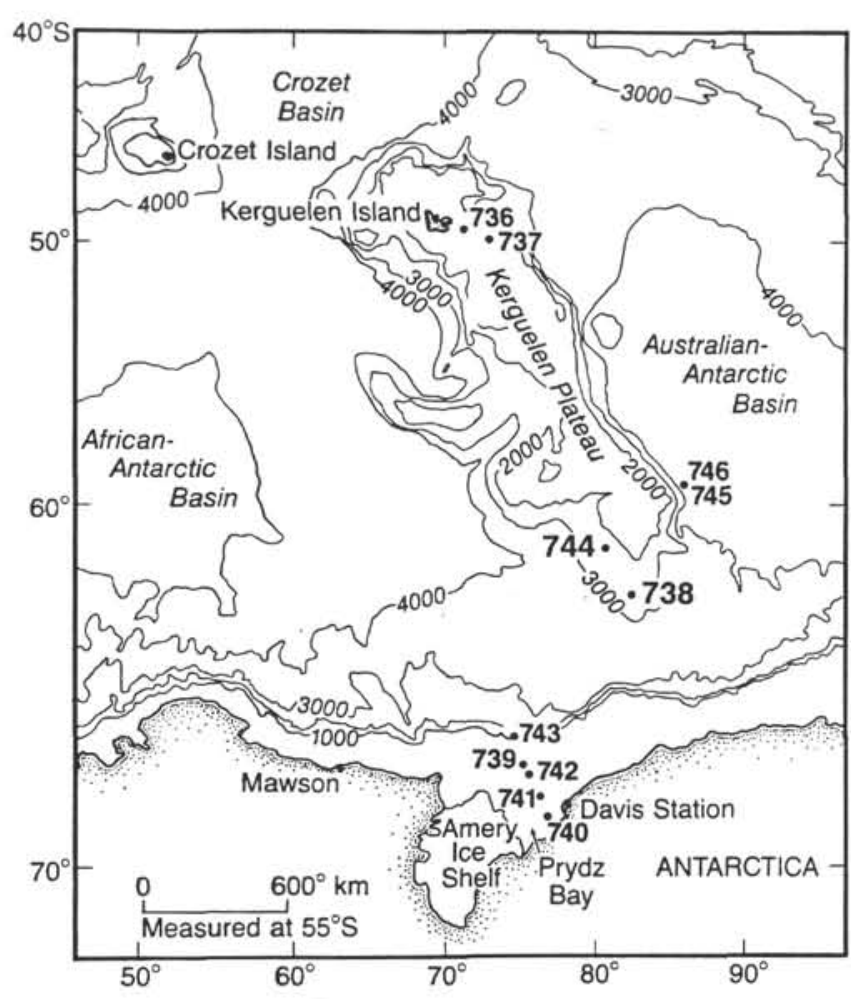

Figure 1. Locations of ODP Sites 738 and 744 on the southern flank of the Kerguelen Plateau. Other sites drilled during Leg 119 are also shown. Contours in meters.

tervals from Paleogene core sections of Site 738 and Paleogene and early Neogene core sections of Hole 744A. Samples were stirred and disaggregated in warm water, ultrasonically cleaned, wet-sieved through a $63 \mu \mathrm{m}$ screen, and then dried over a warm hotplate. Semiquantitative relative abundance estimates were made from randomly strewn samples of about $500-1000$ specimens from the $>63 \mu \mathrm{m}$ size fraction. Each species is recorded in Tables 1, 2, and 3 as Abundant ( $>25 \%$ ), Common ( $16 \%-25 \%$ ), Few $(6 \%-15 \%)$, and Rare $(<1 \%)$. Species that are questionably identified are denoted as "?". Samples with common, few, or rare abundance estimates of planktonic foraminifers are either diluted by biogenic silica or calcareous aggregates that did not break down during routine sample processing.

Foraminifer assemblages exhibiting excellent preservation (E) show no evidence of diagenetic alteration in transmitted light and their test walls are optically translucent. Those with good (G) preservation yield mostly whole foraminifer tests showing minor evidence of dissolution or secondary calcite overgrowth. Assemblages distinguished as having moderate (M) preservation are moderately fragmented, etched, or infilled with fine calcareous matrix, but are still identifiable to the species level. A poor (P) preservation rating is given to samples that have few identifiable specimens due to strong dissolution and fragmentation or calcareous overgrowth.

The generic classification of Loeblich and Tappan (1988) is used for most species discussed in this study. Taxonomic notes are added for species whose generic or specific assignment is unclear. The primary literature sources used for species identification include Subbotina (1953), Bolli (1957), Loeblich and Tappan (1957), Jenkins (1971), and Blow (1979). Primary and secondary types of Paleogene planktonic foraminifer species stored at the U.S. National Museum, particularly those described by
Bolli (1957) and Loeblich and Tappan (1957), were compared with the Antarctic foraminifers to help with species determinations.

All biostratigraphic boundaries are placed at the stratigraphic midpoint between the sample containing the defining marker species and the under- or overlying sample lacking that species.

\section{SITE 738}

\section{Site Description}

Site 738 is located on the southern edge of the Kerguelen Plateau $\left(62^{\circ} 43^{\prime} \mathrm{S}, 82^{\circ} 47^{\prime} \mathrm{E}\right)$ in a water depth of $2253 \mathrm{~m}$ (Fig. 1). Three holes (738A-738C) were drilled at this site, and a $486 \mathrm{~m}$ thick sequence of lower Turonian through Quaternary sediments overlying $38 \mathrm{~m}$ of volcaniclastic rocks and altered basalt was recovered. Only one core with $2.76 \mathrm{~m}$ of sediment was recovered from Hole 738A because of technical problems with the coring assembly.

The advanced piston corer (APC) assembly was used at Hole $738 \mathrm{~B}$ to a depth of 105 meters below seafloor (mbsf) where siliceous stringers were encountered. Core recovery within in this sequence of nannofossil ooze was $98 \%$ (Figs. 2 and 3). Coring continued to $216 \mathrm{mbsf}$ with the extended core barrel (XCB) through nannofossil ooze until interbedded nannofossil chalk and chert stringers were penetrated. Recovery through this interval averaged $61 \%$.

The rotary core barrel was used at Hole $738 \mathrm{C}$ from 197 to $495.6 \mathrm{mbsf}$ where basement rocks were encountered. Core recovery at Hole $738 \mathrm{C}$ averaged only $36 \%$ because of the high abundance of chert layers interbedded with nannofossil chalk that occur particularly in the upper Paleocene and lower Eocene parts of the section (Fig. 2).

\section{Biostratigraphy}

Planktonic foraminifer relative abundance estimates for Holes $738 \mathrm{~B}$ and $738 \mathrm{C}$ are summarized in Tables 1 and 2 . The levels of first appearance datums (FAD's) and last appearance datums (LAD's) of stratigraphically useful taxa are shown in Figure 2 and summarized in Table 4 . The relative abundance of siliceous microfossils is listed only for Hole $738 \mathrm{~B}$ (Table 1), as this group was rarely encountered in Hole $738 \mathrm{C}$.

Foraminifers are abundant in most of the Site 738 samples, but are diluted by biosiliceous sediments from the top of Hole $738 \mathrm{~B}$ to the upper Eocene at about $41 \mathrm{mbsf}$, and at several levels in the middle Eocene. Low foraminifer abundance ratings in parts of the lower Eocene and Paleocene (Table 2) are the result of dilution by lithified calcareous aggregates. Preservation is generally good in most middle Eocene-Oligocene samples, and moderate to good in Paleocene-lower Eocene samples. No levels of strong dissolution or extensive recrystallization were recognized in the Paleogene samples at this site.

Reworked Cretaceous planktonic foraminifers occur in samples ranging from the lower Paleocene through the lowermost Eocene at Hole 738C (Table 2), but were not encountered in any of the Hole 738B samples. Nearly all of the identified species have been reported from upper Maestrichtian sediments at deeper levels in Hole 738C (Huber, this volume).

A major disconformity spanning at least $25 \mathrm{~m}$.y. separates upper Miocene sediments from lower Oligocene sediments between 17.80 and 18.53 mbsf (Caulet, this volume; Barron, Baldauf, et al., this volume). A short hiatus is indicated at about 71 mbsf based on the absence of calcareous nannoplankton Subzone CP14b (Wei and Thierstein, this volume). No other hiatuses have been detected in the Paleogene sections at Site 738.

The following discussion outlines the criteria used for subdivision of the Site 738 sequence into 13 Antarctic Paleogene bio- 
Table 1. Ranges of Paleocene to middle Eocene planktonic foraminifers recovered from ODP Hole 738B. Explanation of the preservation and abundance codes is included in the "Methods" section of this report.

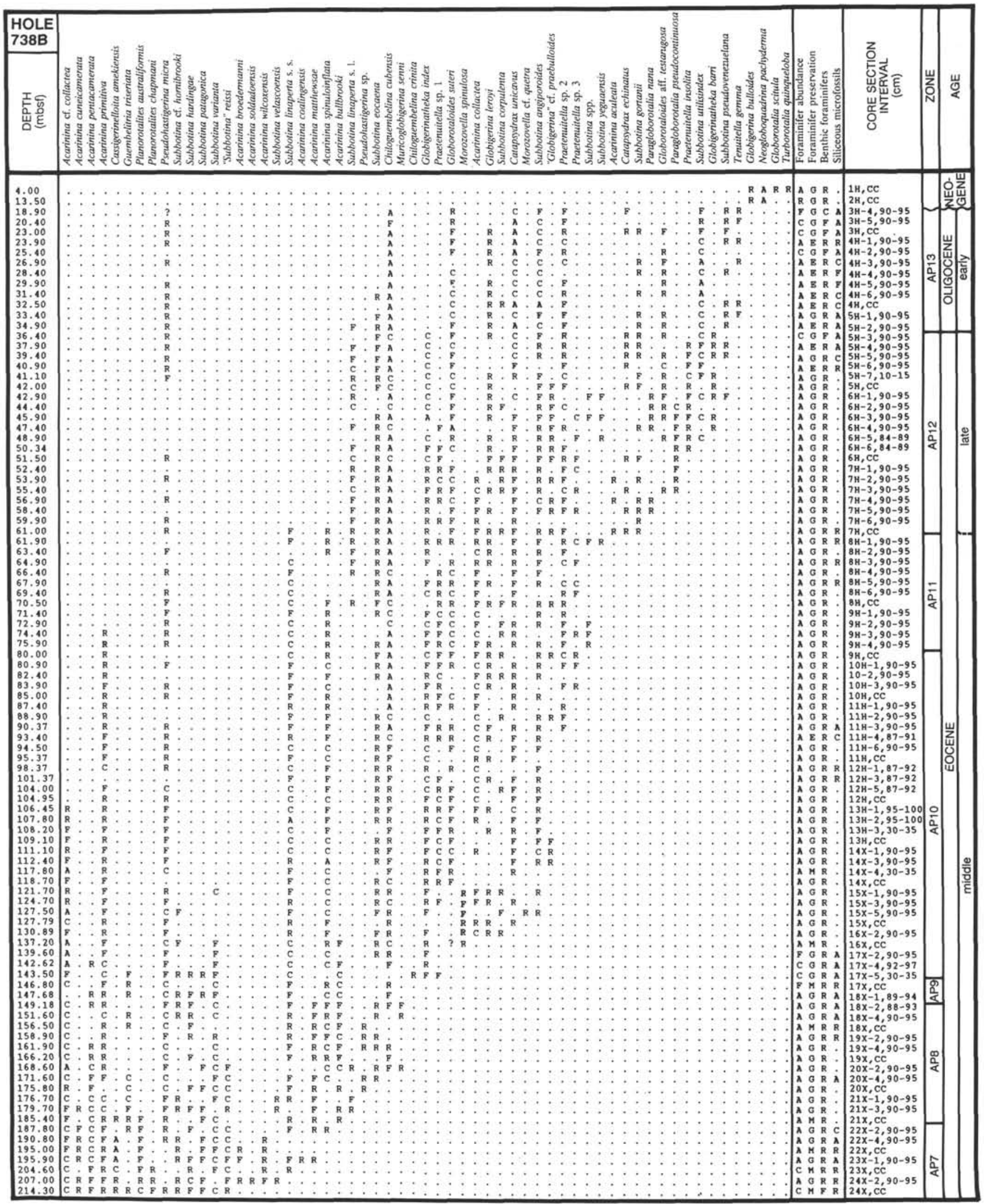


Table 2. Ranges of middle Eocene through Holocene planktonic foraminifers recovered from ODP Hole 738C. Explanation of the preservation and abundance codes is included in the "Methods" section of this report.

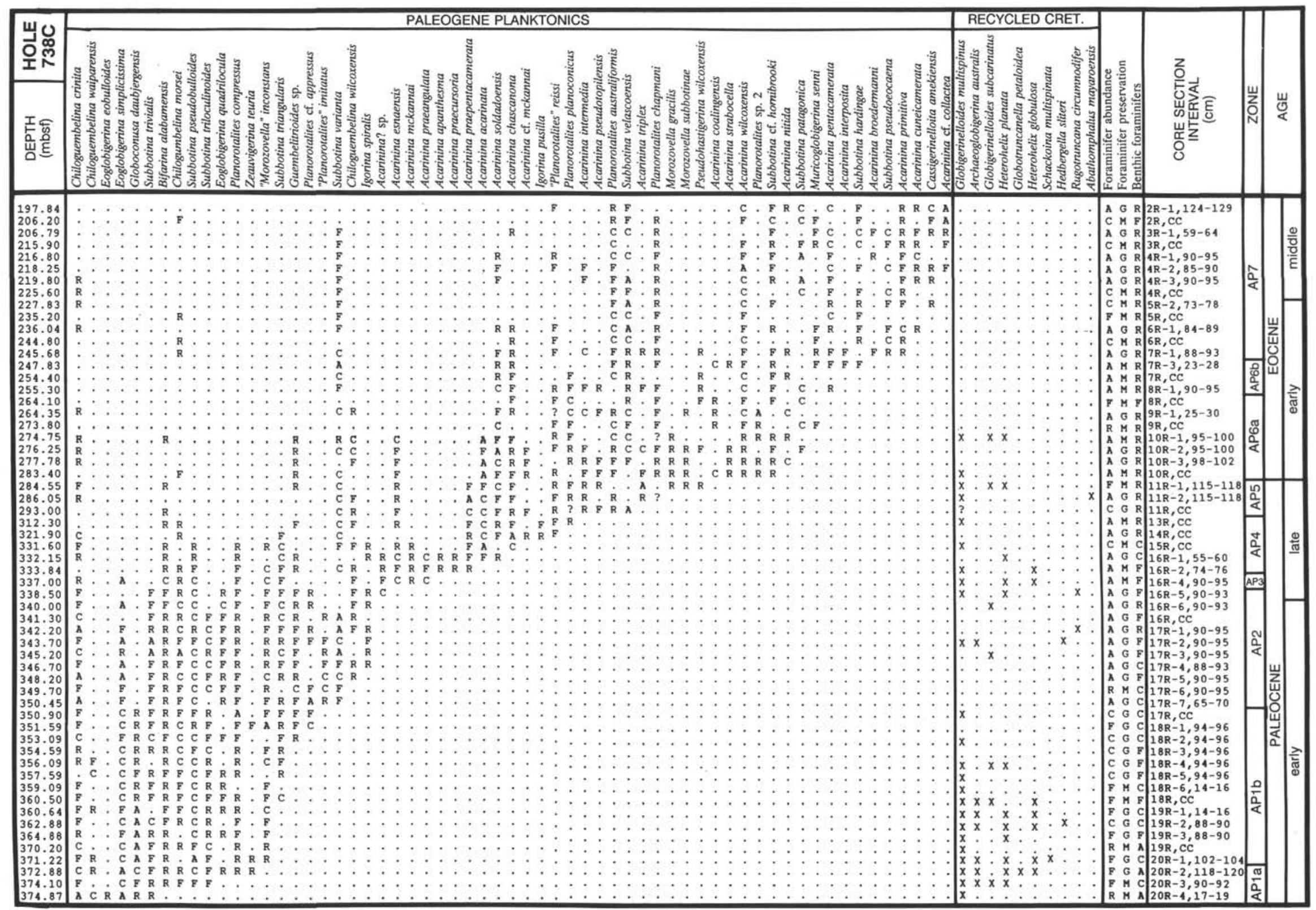


Table 3. Ranges of upper Eocene through Holocene planktonic foraminifers from ODP Site 744. Explanation of the preservation and abundance codes is included in the "Methods" section of this report.

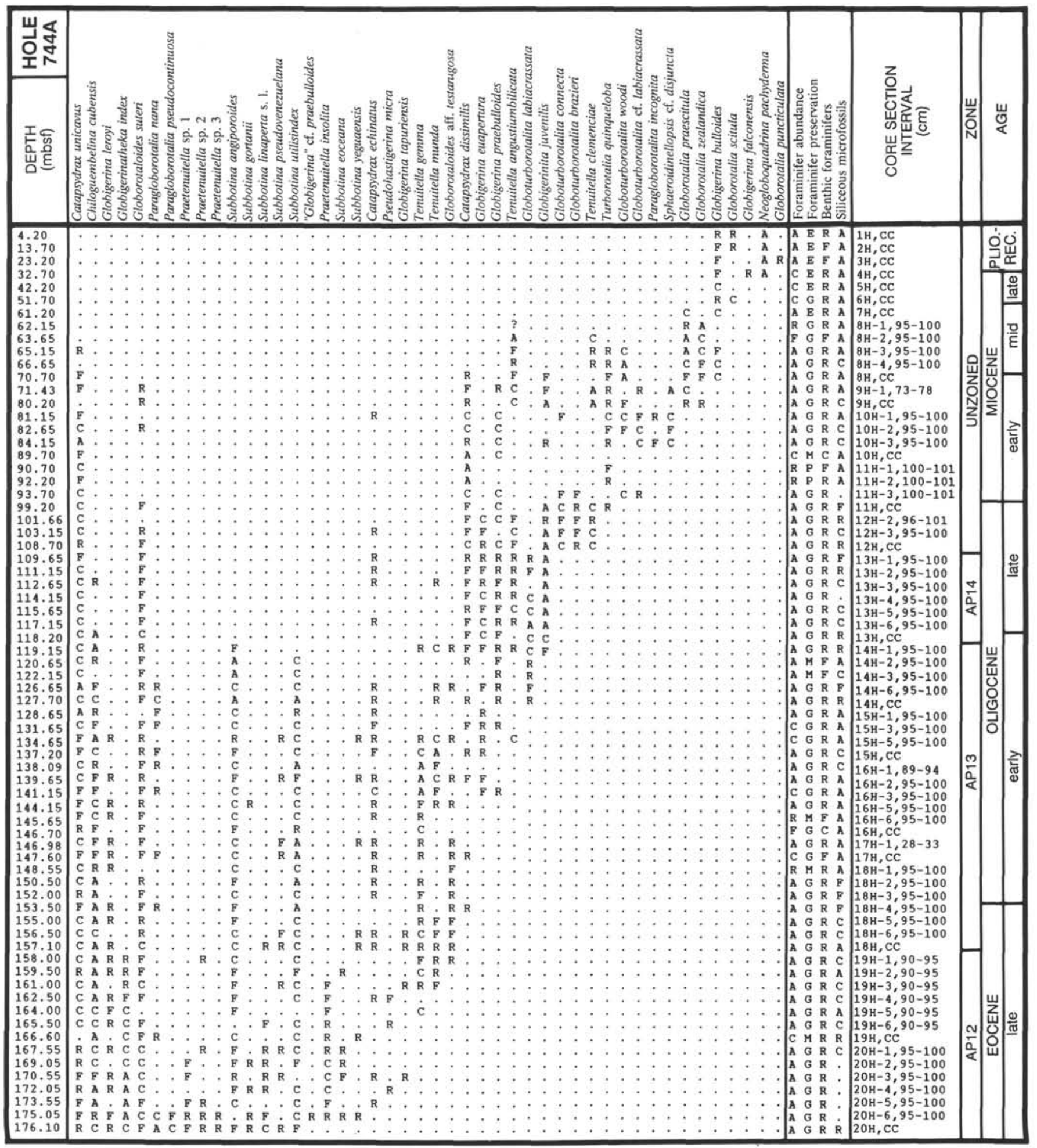

zones. Comments on the species composition and important bioevents recognized within each zone are also included.

\section{Subbotina pseudobulloides Partial Range Zone (AP1)}

Definition. Partial range of the nominate taxon from the FAD of Globoconusa daubjergensis (base) to the FAD of "Planorotalites" imitatus (top).
Reference. Modified from Stott and Kennett (1990) by Huber (this volume).

Stratigraphic range. $376.80-350.07$ mbsf (lower Paleocene).

Comments. The base of this zone was defined by Stott and Kennett (1990) on the initial "common" occurrence of S. pseudobulloides, but was redefined by Huber (this volume) to avoid ambiguity in its recognition. The FAD of $G$. daubjergensis oc- 


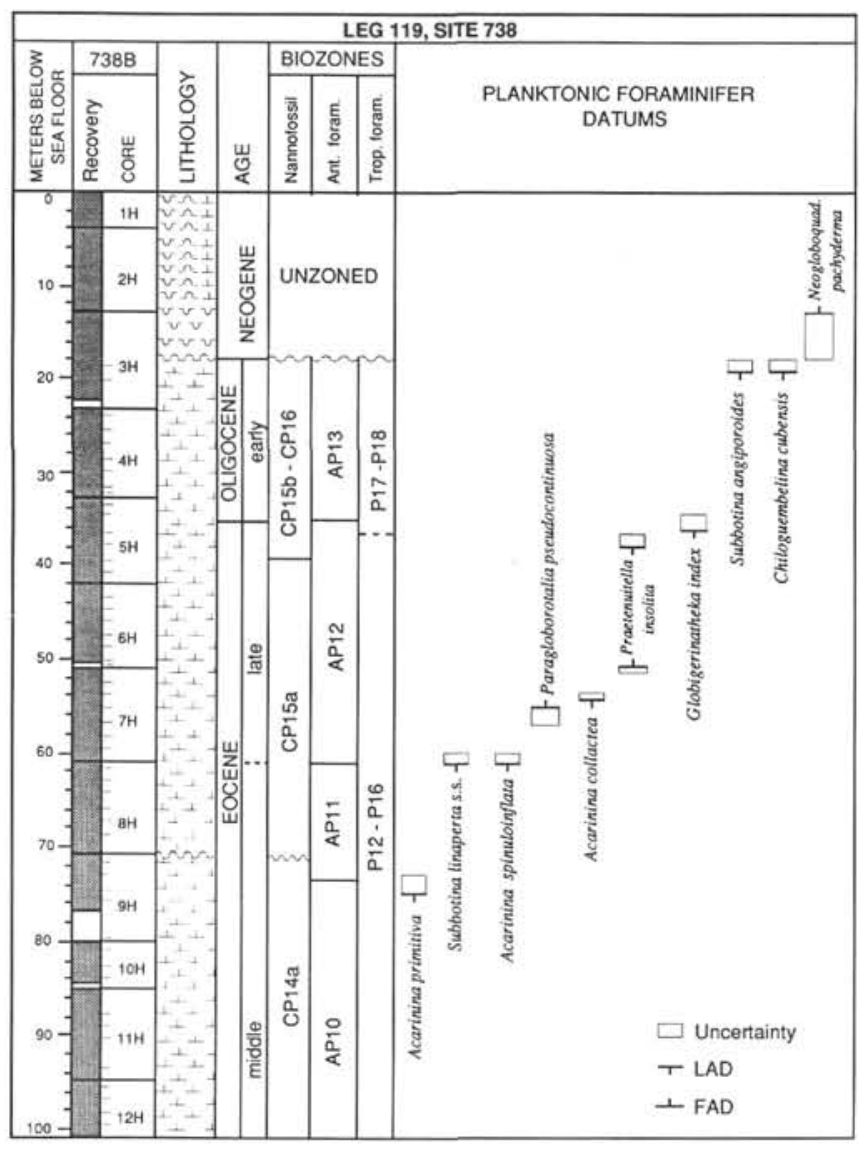

Figure 2. Lithostratigraphy and biostratigraphy of the Cenozoic sequence recovered at ODP Site 738. First and last appearance datums (FAD's and LAD's) of important planktonic foraminifer species are shown along with the Antarctic Paleogene zones based on the biostratigraphic data presented in Tables 1 and 2. Tick marks in the "core recovery" column denote the stratigraphic positions of samples analyzed in this study. Magnetic polarity data from Sakai and Keating (this volume) and Keating (this volume); calcareous nannofossil biozones from Wei and Thierstein (this volume); Antarctic foraminifer zones from Stott and Kennett (1990) and Huber (this volume; this report); tropical foraminifer zones from Berggren and Miller (1988). See Figure 3 for key to lithostratigraphic and magnetostratigraphic symbols.

curs below $(20 \mathrm{~cm})$ the FAD of $S$. pseudobulloides, as has been observed at the Maud Rise (Stott and Kennett, 1990).

\section{Globoconusa daubjergensis Interval Subzone (AP1a)}

Definition. Partial range of the nominate taxon from its initial occurrence (base) to the FAD of "Morozovella" inconstans (top).

Reference. Modified from Stott and Kennett (1990) by Huber (this volume).

Stratigraphic range. 376.80-372.05 mbsf (lower Paleocene).

Comments. Detailed discussion of the faunal changes observed at the Cretaceous/Tertiary boundary and within the Eoglobigerina fringa Zone $(\mathrm{AP} \alpha)$ at Hole $738 \mathrm{C}$ is presented by Huber (this volume). Assemblages within the AP1a Subzone closely resemble early Danian faunas reported from lower latitude sites. Chiloguembelinids and eoglobigerinids are the dominant planktonic foraminifers occurring in this subzone, whereas Subbotina triloculinoides, S. trivialis, $S$. pseudobulloides and $G$. daubjergensis occur in lower abundance. The FAD of Planorotalites compressus is recognized at the top of this subzone.

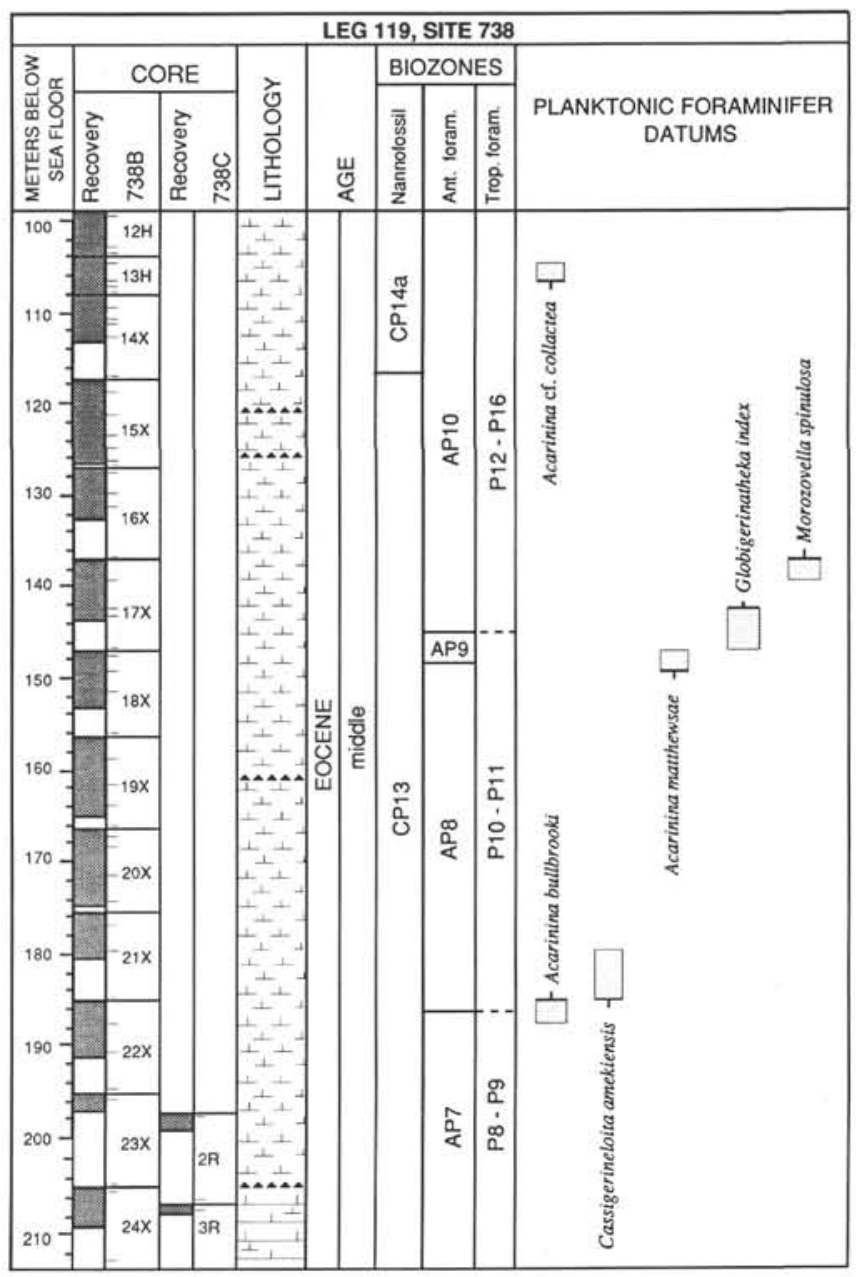

Figure 2 (continued).

"Morozovella" inconstans Interval Subzone (APIb)

Definition. Interval from the FAD of the nominate taxon (base) to the FAD of "Planorotalites" imitatus (top).

Reference. Stott and Kennett (1990).

Stratigraphic range. 372.05-350.07 mbsf (lower Paleocene).

Comments. The lower part of this subzone is dominated by Globoconusa daubjergensis, while Eoglobigerina simplicissima and Subbotina pseudobulloides consistently occur in common abundance. Eoglobigerina quadrilocula, S. triloculinoides, and "Morozovella" inconstans are generally rare components of samples from the AP1b Subzone. Large, high-spired forms with secondary sutural apertures, tentatively identified as Guembelitrioides sp., first occur in the upper part of this subzone. The LAD of Globoconusa daubjergensis is recognized just below the base of the overlying AP2 Zone.

\section{"Planorotalites" imitatus Interval Zone (AP2)}

Definition. Interval from the FAD of the nominate taxon (base) to the FAD of Acarinina mckannai.

Reference. Stott and Kennett (1990).

Stratigraphic range. 350.07-337.75 mbsf (lower-upper Paleocene).

Comments. The nominate species is quite common in the lower part of the AP2 Zone, but is rare and then absent from the upper part. Eoglobigerina simplicissima, S. pseudobulloides, and trilobate subbotinids are the most common elements of this zone, while $E$. quadrilocula, $P$. compressus, and "M." in- 


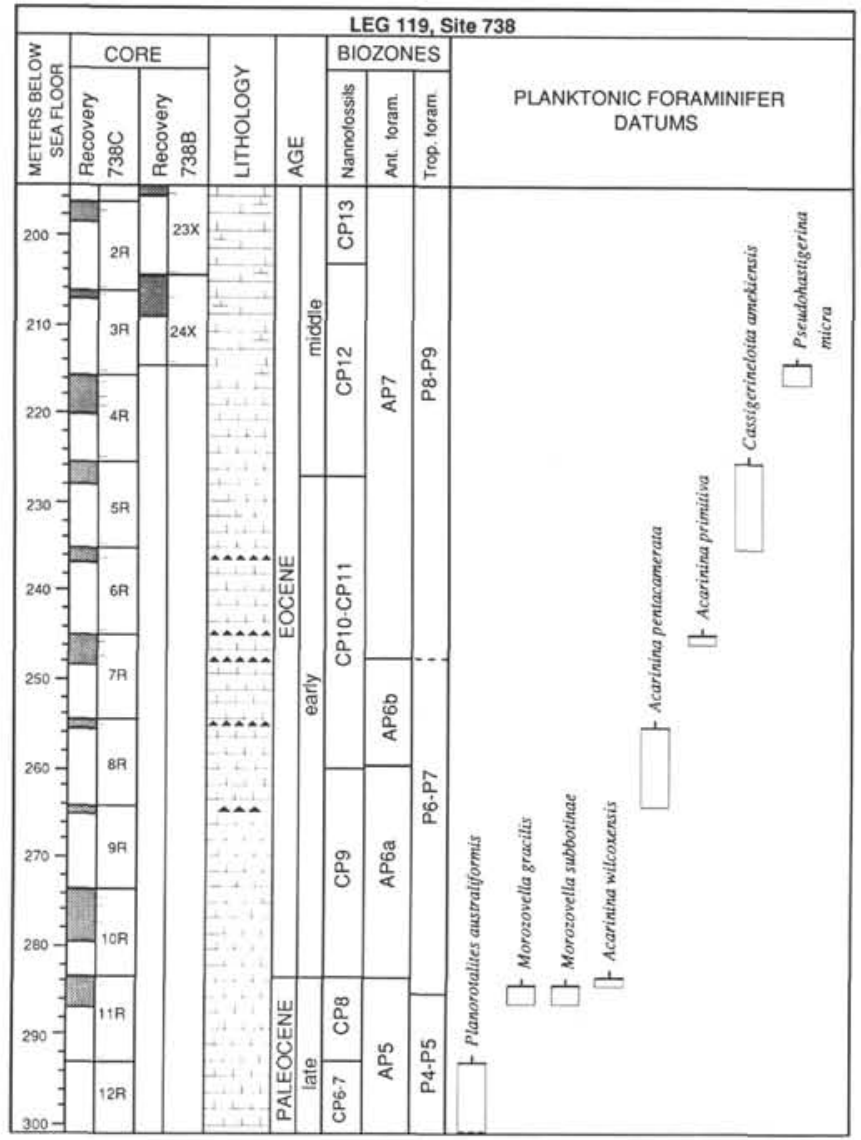

Figure 2 (continued).

constans occur less frequently. Rare Chiloguembelina wilcoxensis first appear near the base of the zone and become increasingly common near the top. Important biostratigraphic events recognized include the FAD of Igorina spiralis (346.70-348.20 mbsf) and the FAD at 340.00-338.50 mbsf of muricate forms tentatively identified as Acarinina? sp. No keeled morozovellids were encountered in samples from this zone.

\section{Acarinina mckannai Interval Zone (AP3)}

Definition. Interval from the FAD of the nominate taxon (base) to the FAD of $A$. praepentacamerata (top).

Reference. Stott and Kennett (1990).

Stratigraphic range. 337.75-335.42 mbsf (upper Paleocene).

Comments. The FAD's of A. mckannai, A. esnaensis, and A. praeangulata occur in the same sample at Site 738 (Fig. 2). The assemblage also contains abundant Eoglobigerina simplicissima and common Bifarina alabamensis and $S$. pseudobulloides.

\section{Acarinina praepentacamerata Interval Zone (AP4)}

Definition. Interval from the FAD of the nominate taxon (base) to the FAD of Planorotalites australiformis.

Reference. Stott and Kennett (1990).

Stratigraphic range. 335.42-302.65 mbsf (upper Paleocene).

Comments. In addition to the nominate taxon, $A$. apanthesma, A. praecursoria, A. acarinata, A. soldadoensis, $A$. chascanona, and "Planorotalites" reissi all make their first appearance within the AP4 Zone. Igorina pusilla first occurs at 331.60$321.90 \mathrm{mbsf}$, enabling correlation with the base of the low latitude Morozovella angulata-Igorina pusilla Partial Range Subzone (P3b) of Berggren and Miller (1988). The AP4 Zone also includes the LAD's of $S$. pseudobulloides, $P$. compressus, I. spi-

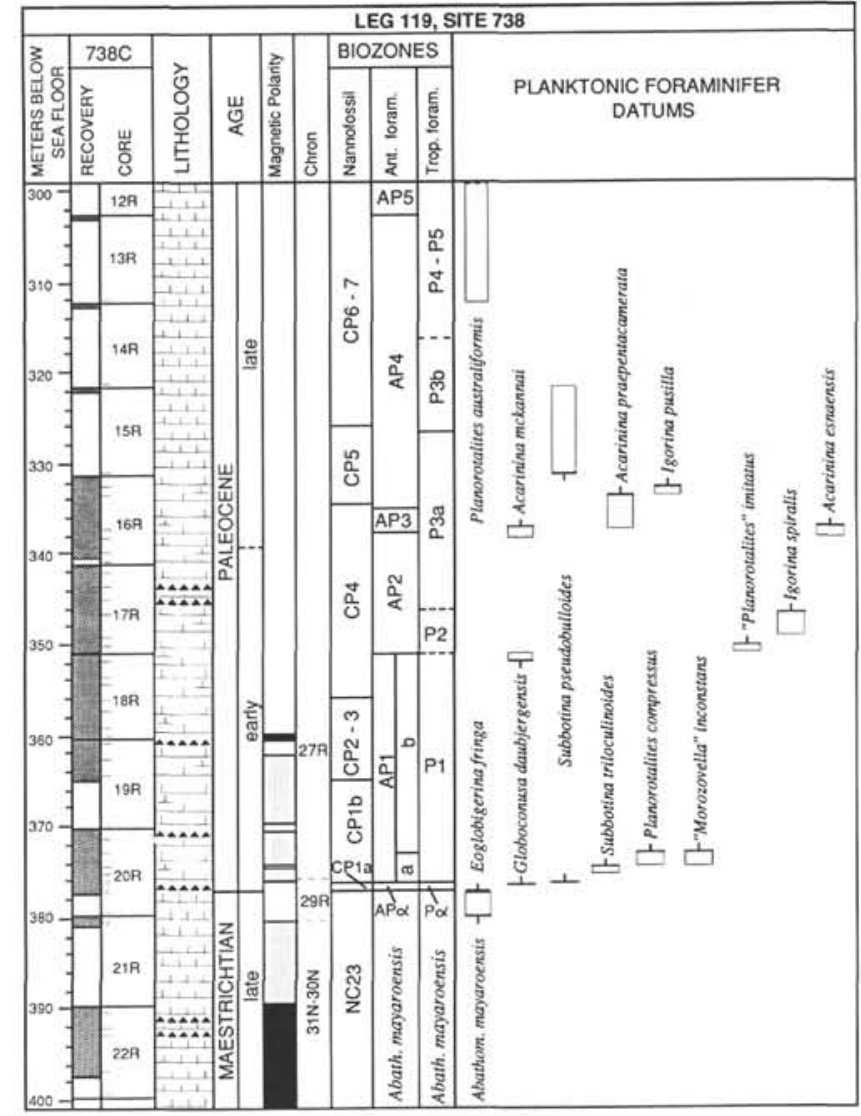

Figure 2 (continued).

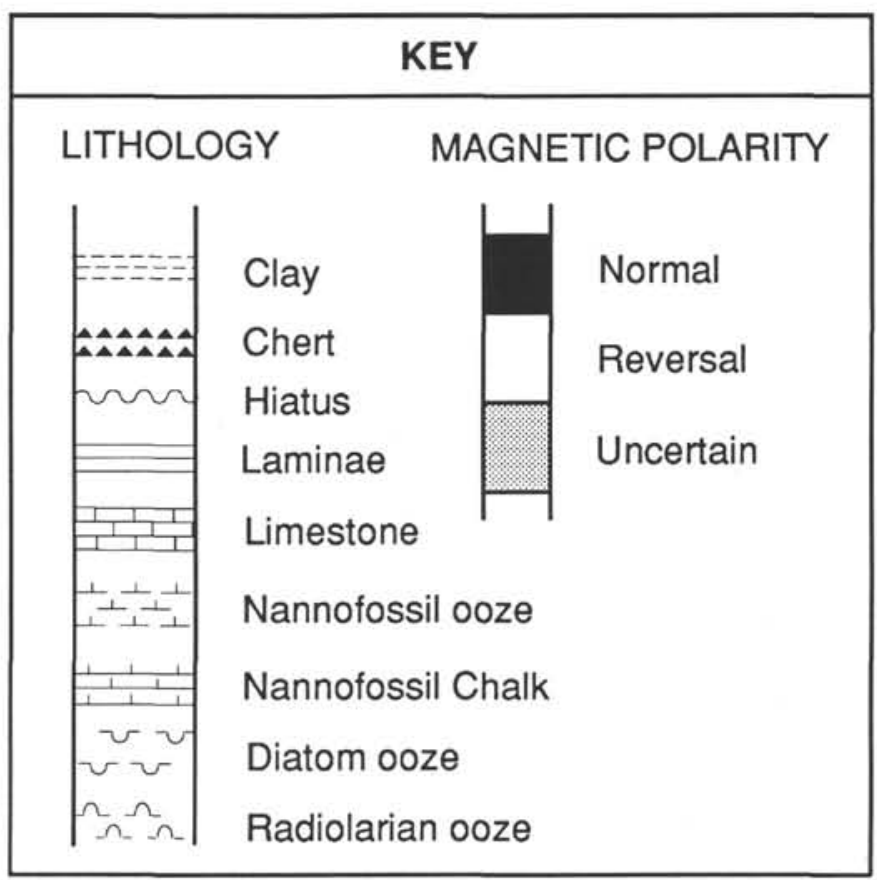

Figure 3. Key to lithostratigraphic and magnetostratigraphic symbols and patterns used in Figures 2 and 4. 
Table 4. Paleocene through Oligocene planktonic foraminifer datums from ODP Site 738.

\begin{tabular}{lc}
\hline & $\begin{array}{c}\text { Depth interval } \\
\text { (mbsf) }\end{array}$ \\
\hline LAD Chiloguembelina cubensis & $13.50-18.90$ \\
LAD Subbotina angiporoides & $13.50-18.90$ \\
LAD Globigerinatheka index & $34.90-36.40$ \\
LAD Praetenuitella insolita & $36.40-37.90$ \\
FAD Praetenuitella insolita & $50.34-51.50$ \\
LAD Acarinina collactea & $52.40-53.90$ \\
FAD Paragloborotalia pseudocontinuosa & $55.40-56.90$ \\
LAD Subbotina linaperta s.s. & $59.90-61.00$ \\
LAD Acarinina spinuloinflata & $59.90-61.00$ \\
LAD Acarinina primitiva & $72.90-74.40$ \\
LAD Acarinina cf. collactea & $104.95-106.45$ \\
LAD Acarinina bullbrooki & $130.89-137.20$ \\
FAD Morozovella spinulosa & $137.20-139.60$ \\
FAD Globigerinatheka index & $143.50-146.80$ \\
LAD Acarinina matthewsae & $147.68-149.18$ \\
LAD Cassigerinelloita amekiensis & $179.70-185.40$ \\
FAD Acarinina bullbrooki & $185.40-187.80$ \\
FAD Pseudohastigerina micra & $214.30-216.80$ \\
FAD Cassigerinelloita amekiensis & $227.83-235.20$ \\
FAD Acarinina primitiva & $245.68-247.83$ \\
FAD Acarinina pentacamerata & $255.30-264.10$ \\
FAD Acarinina wilcoxensis & $283.40-284.55$ \\
FAD Morozovella subbotinae & $284.55-286.05$ \\
FAD Morozovella gracilis & $284.55-286.05$ \\
FAD Planorotalites australiformis & $293.00-312.30$ \\
LAD Subbotina pseudobulloides & $321.90-331.60$ \\
FAD Igorina pusilla & $321.90-331.60$ \\
FAD Acarinina praepentacamerata & $333.84-337.00$ \\
FAD Acarinina mckannai & $337.00-338.50$ \\
FAD Acarinina esnaensis & $337.00-338.50$ \\
FAD Igorina spiralis & $346.70-348.20$ \\
\hline FAD = first appearance datum; LAD & last appearance \\
datum. & \\
&
\end{tabular}

ralis, and $A$. mckannai within the interval 331.60-321.90 mbsf. Keeled morozovellids characteristic of lower latitudes are absent. Trilobate subbotinids and chiloguembelinids comprise the bulk of the fine fraction throughout the zone.

\section{Planorotalites australiformis Interval Zone (AP5)}

Definition. Interval from the FAD of the nominate taxon (base) to the FAD of $A$. wilcoxensis (top).

Reference. Stott and Kennett (1990).

Stratigraphic range. 302.65-283.98 mbsf (uppermost Paleocene).

Comments. There is a large stratigraphic gap between the first sample in which $P$. australiformis occurs (119-738C-11R-CC) and the next underlying sample analyzed (119-738C-13R-CC), as no sediment was recovered in Core 119-738C-12R (Fig. 2). Acarinina intermedia, A. pseudotopilensis, A. triplex, Subbotina velascoensis, Pseudohastigerina wilcoxensis, and the tropical marker species Morozovella subbotinae and $M$. gracilis also have their first appearances within the AP5 Zone. The most common species are A. acarinata and Subbotina varianta, while planorotalitids ( $P$. australiformis, $P$. planoconicus, and " $P$ " reissi) are less abundant. The high diversity of acarininids and presence of keeled morozovellids within this zone attest to expansion of warm surface waters into the southern high latitudes during latest Paleocene time.

\section{Acarinina wilcoxensis Interval Zone (AP6)}

Definition. Interval from the FAD of $A$. wilcoxensis (base) and the FAD of Acarinina primitiva (top).

Reference. Stott and Kennett (1990).

Stratigraphic range. 283.98-246.76 mbsf (lower Eocene).
Subbotina inaequispira Partial Range Subzone (AP6a)

Definition. Interval from the FAD of $A$. wilcoxensis (base) to the FAD of Acarinina pentacamerata (top).

Reference. Stott and Kennett (1990).

Stratigraphic range. 283.98-259.70 mbsf (lowermost Eocene).

Comments. The assemblages in this subzone strongly resemble those of the AP5 Zone, indicating persistence of warm climatic conditions in the southern high latitudes during the earliest Eocene. Acarinina wilcoxensis is rare in the lower part of this zone, but increases in abundance in stratigraphically higher samples. Acarinina strabocella, A. nitida, Pseudohastigerina chapmani, and Subbotina patagonica first occur within the AP6a Subzone. Planorotalites australiformis, $P$. chapmani, and $P$. planoconicus are rare to common at several levels. It is likely that the species concept of $S$. patagonica in this study is the same as that of $S$. inaequispira used by Stott and Kennett (1990) at the Maud Rise, as the stratigraphic levels of their first occurrence are similar.

\section{Acarinina pentacamerata Interval Subzone (AP6b)}

Definition. Interval from the FAD of the nominate taxon (base) to the FAD of $A$. primitiva (top).

Reference. Stott and Kennett (1990).

Stratigraphic range. 259.70-246.76 mbsf (lower Eocene).

Comments. Acarinina pentacamerata is a rare component of the AP6b assemblages at Hole $738 \mathrm{C}$, whereas $A$. wilcoxensis and $S$. varianta occur in greater abundance. Planorotalites planoconicus last occurs in the middle of the subzone, whereas $P$ australiformis and $P$. chapmani range throughout in relatively low abundance. The LAD's of Acarinina interposita and Subbotina hardingae occur near the top of this subzone. Overall acarininid abundance and diversity is considerably diminished compared to the AP5 Zone and AP6a Subzone, and morozovellids are absent.

\section{Acarinina primitiva Interval Zone (AP7)}

Definition. Interval from the FAD of the nominate taxon (base) to the FAD of Acarinina bullbrooki (top).

Reference. Stott and Kennett (1990).

Stratigraphic range. $246.76-186.60 \mathrm{mbsf}$ (lower to middle Eocene).

Comments. Acarinina primitiva consistently occurs in relatively low abundance throughout this zone (Tables 1,2$)$. More common species include $A$. pentacamerata, $A$. cf. $A$. collactea, and several subbotinids. The distinctive species Cassigerinelloita amekiensis has its FAD within the lower part of the AP7 Zone (235.20-227.83 mbsf) and increases in abundance toward the top of this zone. The FAD of Guembelitria triseriata is above that of $C$. amekiensis in the AP7 Zone at Site 738, which is contrary to the order of first occurrence observed at Leg 120 Site 749B ( $\mathrm{Li}$ Qianyu and Radford, in press). Other important datums that occur in the AP7 Zone include the FAD's of Subbotina linaperta s.s. and Pseudohastigerina micra and the LAD of $P$ australiformis.

\section{Acarinina bullbrooki Interval Zone (AP8)}

Definition. Interval from the FAD of $A$. bullbrooki (base) to the LAD of Acarinina matthewsae (top).

Reference. Modified in this study after Stott and Kennett (1990).

Stratigraphic range. 186.60-148.43 mbsf (middle Eocene).

Comments. Acarinina bullbrooki is initially rare in the lower part of this zone, but increases in abundance in the upper part. Species with common occurrences include $A$. cf. $A$. collactea, A. pentacamerata, Subbotina varianta, and "Subbotina" reissi. 
The LAD's of Acarinina cuneicamerata, C. amekiensis, and $P$. australiformis occur near the base of the AP8 Zone.

\section{Acarinina matthewsae Interval Zone (AP9)}

Definition. Interval from the last occurrence of the nominal taxon (base) to the first occurrence of Globigerinatheka index (top).

\section{Reference. This study.}

Stratigraphic range. 148.43-145.15 mbsf (middle Eocene).

Comments. Because the first occurrence of Pseudohastigerina micra is below the Acarinina bullbrooki Zone at Site 738, the P. micra Zone (AP9) of Stott and Kennett (1990) cannot be recognized as originally defined. Rather than eliminate one of these two zones, the AP9 Zone is redefined in the present study. Common species within this zone include Acarinina bullbrooki, A. spinuloinflata, Acarinina cf. A. collactea, P. micra, Subbotina linaperta s.s., S. varianta, and Praetenuitella sp. 3. Guembelitria triseriata is a conspicuous element of the lower levels of this zone, but is rare in the upper levels.

\section{Acarinina collactea Partial Range Zone (AP10)}

Definition. Partial range of the nominate taxon from the FAD of $G$. index (base) to the LAD of Acarinina primitiva (top).

Reference. Stott and Kennett (1990).

Stratigraphic range. 145.15-73.65 mbsf (middle Eocene).

Comments. Globigerinatheka index is relatively rare in the lower part of this zone, but its abundance increases in stratigraphically higher levels. The oldest AP10 fauna includes abundant specimens of $A$. cf. $A$. collactea, common $A$. bullbrooki, and rare to few specimens of Morozovella spinulosa. The latter species consistently occurs within a $15.5 \mathrm{~m}$ interval in the lower part of the AP10 Zone (137.20-121.70 mbsf). Other species that characterize the AP10 Zone include rare to abundant $S$. linaperta s.s., rare to few $A$. primitiva, and rare to common $A$. collactea. Chiloguembelinids range throughout the zone, but become particularly abundant at the upper levels. Globorotaloides suteri, Catapsydrax unicavus, and Subbotina angiporoides all first appear within the AP10 Zone and occur in rare to common abundance.

\section{Globigerinatheka index Partial Range Zone (AP11)}

Definition. Partial range of the nominate taxon from the LAD of $A$. primitiva (base) to the last occurrence of $S$. linaperta s.s.

Reference. Stott and Kennett (1990).

Stratigraphic range. 73.65-60.45 mbsf (middle Eocene).

Comments. The LAD's of forms referable to $S$. linaperta s.s. and $A$. spinuloinflata occur at the same level, about $25 \mathrm{~m}$ below the Eocene/Oligocene boundary (Fig. 2). Abundant chiloguembelinids, common to abundant $S$. linaperta, few to common $G$. index, rare to common $A$. collactea and $G$. suteri, and rare to few $S$. angiporoides and Globorotaloides unicavus range through the AP11 Zone.

\section{Globorotaloides suteri Partial Range Zone (AP12)}

Definition. Interval from the LAD of S. linaperta s.s. (base) to the LAD of $G$. index (top).

Reference. Stott and Kennett (1990).

Stratigraphic range. 60.45-35.65 mbsf (upper Eocene).

Comments. Assemblages in the AP12 Zone are dominated by chiloguembelinids and, in the middle to upper part, $G$. index. Significant events in this zone include: (1) the FAD of Paragloborotalia pseudocontinuosa (56.90-55.40 mbsf), (2) the LAD of A. collactea (106.45-104.95 mbsf), (3) the FAD of Praetenuitella insolita (51.50-50.34 mbsf), and (4) the LAD of $P$. insolita (37.90-36.40 mbsf). Globorotaloides suteri is relatively com- mon, while $G$. unicavus, $S$. angiporoides, and tenuitellids occur in lower abundance. Subbotina gortanii and Paragloborotalia nana are rare and sporadic in their occurrence.

\section{Subbotina angiporoides Interval Zone (AP13)}

Definition. Interval from the LAD of $G$. index (base) to the LAD of the nominate taxon (top).

Reference. Stott and Kennett (1990).

Stratigraphic range. $35.65-17.80$ mbsf (lower Oligocene).

Comments. Planktonic foraminifers in this zone are characterized by low dominance-high diversity assemblages of $\mathrm{C}$. $\mathrm{cu}$ bensis, $C$. unicavus, $C$. suteri, $S$. angiporoides, and $S$. utilisindex. Globigerina leroyi, Globorotaloides aff. G. testarugosa, S. gortanii, and $P$. micra range throughout in low abundance. The FAD of Tenuitella gemma occurs at the bottom of the AP13 Zone in Sample 119-738B-5H-1, 90-95 cm (34.90-33.40 mbsf).

\section{SITE 744}

\section{Site Description}

Site 744 is located on the southern Kerguelen Plateau $\left(61^{\circ} 35^{\prime} \mathrm{S}\right.$, $80^{\circ} 36^{\prime} \mathrm{E}$ ), over $200 \mathrm{~km}$ northwest of Site 738 (Fig. 1). This site was cored in order to obtain a more complete Neogene and Oligocene section than was recovered at Site 738. Three holes were drilled at Site 744 (744A-744C), and a $176.1 \mathrm{~m}$ sequence of upper Eocene through Holocene sediments was cored. Composite recovery was over $95 \%$. Hole $744 \mathrm{~A}$ was drilled at $2307 \mathrm{~m}$ water depth using the APC. Core recovery averaged $62 \%$ for the first $80 \mathrm{~m}$ and over $98 \%$ for the remaining $96 \mathrm{~m}$ (Fig. 4).

Pliocene to Holocene sediments are predominantly composed of diatom ooze with a minor amount of biogenic calcite. Transition from predominantly biosiliceous to calcareous ooze occurs at about 23 mbsf (Fig. 4). Siliceous microfossils are abundant to common in the coarse $(>63 \mu \mathrm{m})$ sieved residues of all Neogene and most lower Oligocene samples (Table 3 ). They are absent to common in upper Oligocene and upper Eocene samples.

The oldest record of ice-rafted sediments was recovered from the coarse seived residue of Sample 119-744A-17H-CC (147.60 mbsf), which is early early Oligocene in age. This corroborates evidence from the Ross Sea region that continental scale glaciation was established in East Antarctica at least by early Oligocene time (Barrett, 1989).

\section{Biostratigraphy}

Planktonic foraminifers are common to abundant in nearly all of the recovered sections and foraminifer preservation is moderate to excellent in nearly all samples (Table 4). Highly fragmented and strongly etched foraminifer tests recovered between 89.70 and 93.70 mbsf indicate the presence of corrosive waters for a brief time during the early Miocene.

The most significant disconformity at Site 744 occurs in the middle Oligocene at about $118 \mathrm{mbsf}$, where nearly $3.5 \mathrm{~m} . \mathrm{y}$. of sediment record is missing (Barron, Baldauf, et al,, this volume). Other hiatuses are recognized at about $22 \mathrm{mbsf}(1.4 \mathrm{~m} . \mathrm{y}$. missing), 24 mbsf (2.9 m.y. missing), 53 mbsf (1.0 m.y. missing), 55 mbsf (0.9 m.y. missing), and 97 mbsf ( 2.7 m.y. missing) based primarily on strontium isotope studies (Barrera et al., this volume) and correlation of diatom (Baldauf and Barron, this volume) and radiolarian biostratigraphy (Caulet, this volume) with the magnetic polarity record (Keating, this volume).

\section{Globorotaloides suteri Partial Range Zone (AP12)}

Stratigraphic range. 176.10-156.80 mbsf (upper Eocene).

Comments. Globigerinatheka index is abundant to common in samples from the bottom of the Hole 744A sequence to about 164.00 mbsf, but is a rare component of assemblages from near 


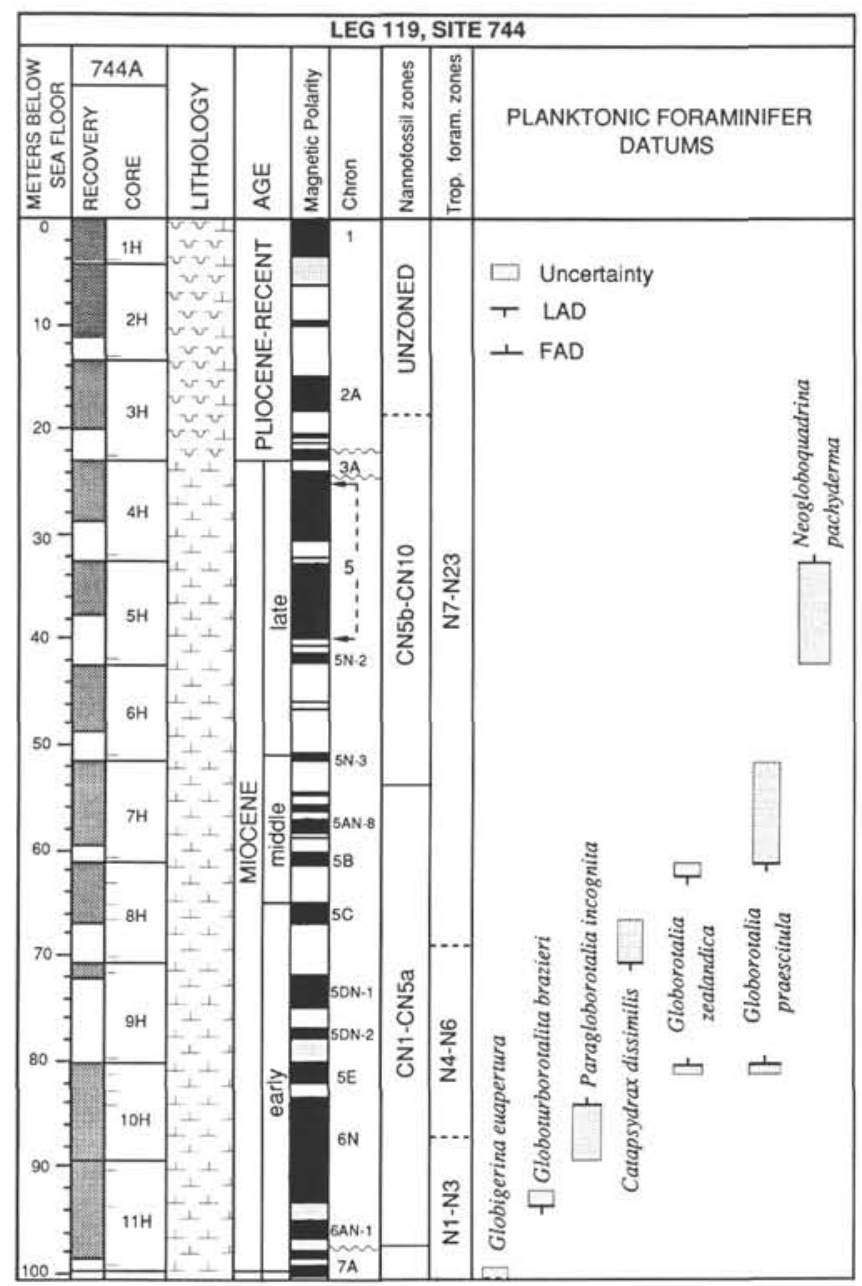

Figure 4. Lithostratigraphy and biostratigraphy of the uppermost Eocene through Holocene sequence recovered at ODP Site 744 based on biostratigraphic data presented in Table 3. See Figures 2 and 3 for additional explanation. the top of the AP12 Zone (Table 3). This contrasts with the common relative abundance estimates observed just prior to the last appearance of $G$. index at Hole 738B (Table 2). Absence of $S$. linaperta s.s., $A$. spinuloinflata, and $A$. collactea from the lowermost Hole 744A samples indicates that the top of the upper middle Eocene $G$. index Zone (AP11) was not cored.

The LAD of $P$. insolita occurs in uppermost Eocene sediments associated with Chron 15R-2. Although this datum is recognized below the LAD of $G$. index at both Kerguelen Plateau sites, Nocchi et al. (in press) found that the LAD of $P$. insolita occurs in lowermost Oligocene sediments above the LAD of $G$. index. No comparative data are available from the Maud Rise, as Stott and Kennett (1990) did not identify $P$. insolita in any of their samples.

As observed at Hole 738B, the AP12 Zone assemblages contain common to abundant chiloguembelinids, few to common $G$. suteri, S. angiporiodes, and S. utilisindex, rare to common G. unicavus. Paragloborotalia pseudocontinuosa and S. linaperta s.l. occur only in the lower part of the zone.

Pseudohastigerina micra was found in low abundance in only three samples from the AP12 Zone. The last occurrence of $P$. micra at Hole $744 \mathrm{~A}$, estimated at about $38.0 \mathrm{Ma}$ (Table 5), is older than the $37.1 \mathrm{Ma}$ age reported for this species at the Maud Rise (L. D. Stott, pers. comm., 1990).

\section{Subbotina angiporoides Interval Zone (AP13)}

Stratigraphic range. 156.80-117.68 mbsf (lower Oligocene).

Comments. The lower Oligocene planktonic foraminifer assemblages from Hole 744A are similar to coeval assemblages recorded from Hole 738B, with common occurrences of $S$. angiporoides, $S$. utilisindex, chiloguembelinids, and catapsydracids, rare to few occurrences of tenuitellids and globigerinids, and rare occurrences of Globorotaloides aff. G. testarugosa. The upper AP13 Zone assemblages are younger than the AP13 fauna from Hole 738B, as they contain P. nana, $C$. dissimilis, G. euapertura, T. munda, T. angustiumbilicata, and G. labiacrassata.

\section{Globoturborotalita labiacrassata Interval Zone (AP14)}

Definition. Interval from the LAD of $S$. angiporoides to the LAD of the nominate taxon.

Reference. Stott and Kennett (1990).

Stratigraphic range. 117.68-109.18 mbsf (upper lower-upper Oligocene).

Table 5. Late Eocene through Holocene planktonic foraminifer datums from ODP Site 744. Ages for the Site $\mathbf{7 4 4}$ datums are based on the age model presented by Barron, Baldauf, et al. (this volume).

\begin{tabular}{|c|c|c|c|c|}
\hline \multirow[b]{2}{*}{ Site 744 datums $^{\mathrm{a}}$} & \multirow{2}{*}{$\begin{array}{l}\text { Depth interval } \\
\text { (mbsf) }\end{array}$} & \multirow[b]{2}{*}{ Chron } & \multicolumn{2}{|c|}{ Age (Ma) } \\
\hline & & & Previous study & This study \\
\hline LAD Globorotalia zealandica & $61.20-62.15$ & SBN & $b_{17.6}$ & 16.7 \\
\hline LAD Catapsydrax dissimilis & $66.65-70.70$ & $5 C$ & $b_{17.6}$ & 16.7 \\
\hline FAD Globorotalia praescitula & $80.20-81.15$ & SDN-2? & $\mathrm{b}_{17.7}$ & 18.1 \\
\hline FAD Globorotalia zealandica & $80.20-81.15$ & $5 \mathrm{DN}-2 ?$ & & 18.1 \\
\hline LAD Globoturborotalita brazieri & $92.20-93.70$ & $6 \mathrm{~N}$ & & 20.5 \\
\hline LAD Globigerina euapertura & $99.20-101.66$ & $7 \mathrm{AN}$ & & 26.4 \\
\hline FAD Globoturborotalita brazieri & $108.70-109.65$ & $8 \mathrm{~N}$ & & 27.3 \\
\hline LAD Globoturborotalita labiacrassata & $108.70-109.65$ & $8 \mathrm{~N}$ & $c_{28.2}$ & 27.3 \\
\hline LAD Chiloguembelina cubensis & $117.15-118.20$ & $11 \mathrm{~N}$ & $\mathrm{c}, \mathrm{d}_{30.1}$ & $28.5-32.0$ \\
\hline LAD Subbotina angiporoides & $118.20-119.15$ & $11 \mathrm{R}$ & $c, d_{32.0}$ & 32.1 \\
\hline LAD Globigerinatheka index & $157.10-158.00$ & $15 \mathrm{~N}-2$ & $c, d_{37.1}$ & 37.3 \\
\hline LAD Praetenuitella insolita & $159.50-161.00$ & $15 \mathrm{R}-2$ & & 37.9 \\
\hline LAD Pseudohastigerina micra & $161.00-162.50$ & $16 \mathrm{~N}-1$ & $d_{37.1}$ & 38.0 \\
\hline
\end{tabular}

${ }^{\mathrm{a}} \mathrm{FAD}=$ first appearance datum; LAD = last appearance datum.

b Berggren et al. (1985a).

${ }^{c}$ Berggren et al. (1985b).

d L. D. Stott (pers. comm., 1990). 
Comments. The level of the last abundant occurrence of $C$. cubensis (Sample 119-744A-13H-CC) is overlain by several samples that lack this species and one sample (Sample 119-744A$13 \mathrm{H}-3,95-100 \mathrm{~cm}$ ) that yields very rare $C$. cubensis specimens. The isolated occurrence higher in the section is considered to be the result of reworking.

The LAD of $S$. angiporoides is less than $2 \mathrm{~m}$ below that of C. cubensis whereas these datums are more widely spaced in deep sea pelagic carbonate sequences at other southern high latitude sites (Stott and Kennett, 1990; Nocchi et al., in press; Berggren, in press a). This indicates that the 118-116 mbsf interval is either very condensed or discontinuous due to the presence of a disconformity. Subbotina angiporoides is common to abundant in most of the AP14 Zone samples.

Planktonic foraminifer assemblages from this zone contain very abundant Globigerinita juvenilis, common G. labiacrassata and catapsydracids, rare to common $G$. euapertura, G. praebulloides, and tenuitellids, and rare to few $G$. suteri.

The LAD of $G$. labiacrassata correlates with the top of a normal polarity sequence that is assigned to Chron $8 \mathrm{~N}$. This datum was reported in older sediments associated with Chron C9N, at Maud Rise Sites 689 and 690 (Stott and Kennett, 1990) and Kerguelen Plateau Sites 747 and 748 (Berggren, in press a).

\section{Upper Oligocene-Neogene}

Upper Oligocene planktonic foraminifer assemblages above the AP14 Zone are characterized by having abundant Globigerinita juvenilis, common $G$. praebulloides, few to common $C$. dissimilis and Globoturborotalita connecta, and rare to common $C$. unicavus, Globorotaloides aff. G. testarugosa, and T. clemenciae.

Rare to few specimens of Globoturborotalita brazieri consistently occur in samples from its FAD in the interval 109.65108.70 mbsf, correlative with Chron C8N, to its LAD in the interval 93.70-92.20 mbsf, which is associated with Chron C6N (Table 5; Fig. 4).

Globigerina euapertura first occurs in relatively low abundance in lower Oligocene sediments and ranges through the upper Oligocene, occurring in rare to common abundance. The LAD of this species between 101.66 and 99.20 mbsf is immediately below the Miocene/Oligocene boundary within an interval recognized as Chron 7AN. This closely parallels the G. euapertura distribution reported at Kerguelen Plateau Sites 747 and 748 (Berggren, in press a, b). It is clear from the Kerguelen Plateau studies that the LAD of $G$. euapertura is a good marker for the Miocene/Oligocene boundary in Austral regions.

Lower Miocene assemblages are predominantly composed of C. dissimilis, C. unicavus, and $G$. praebulloides, with less frequent occurrences of Turborotalia quinqueloba, Globoturborotalita woodi, and a distinctive taxon referable as Globoturborotalita cf. G. labiacrassata. The first occurrence of Paragloborotalia incognita between 89.70 and $84.15 \mathrm{mbsf}$, associated with Chron $\mathrm{C} 6 \mathrm{~N}$, enables approximate correlation with the base of Zone N4 (Cifelli and Scott, 1983; Berggren et al., 1983). This occurrence is younger than the $P$. incognita FAD in Chron C6B reported at the Rio Grande Rise (Berggren et al., 1983), perhaps because of the poor foraminifer preservation and the presence of a disconformity in the upper part of Core 119-744A-11H.

The LAD of $C$. dissimilis denotes the boundary between tropical Zones N6 and N7 (Blow, 1969). At Hole 744A, this datum level occurs in a lower Miocene interval identified as Chron C5C (70.70-66.65 mbsf), over $10 \mathrm{~m}$ above the FAD's of Globorotalia zealandica and G. praescitula (Fig. 4). This is inconsistent with the nearly coincident $C$. dissimilis-G. zealandica- $G$. praescitula datums associated with Chron C5D at the Rio Grande Rise (Berggren et al., 1983; Berggren et al., 1985a). Berggren (in press b) identified the LAD of $C$. dissimilis just above the top of Chron C5E at ODP Site 747 on the Kerguelen Plateau.

The LAD of $G$. zealandica occurs in a middle Miocene interval (62.15- 61.20 mbsf) associated with Chron C5B (Tables 3, 5 ). This is younger than the extinction level reported as Chron C5C at the Rio Grande Rise (Berggren et al., 1983) and Kerguelen Plateau Site 751 (Berggren, in press b), but slightly older than the Chron C5AD level reported from Kerguelen Plateau Site 747 (Berggren, in press b). The LAD of Globorotalia praescitula occurs in middle to upper Miocene sediments above the closely spaced sampled core sections, between 61.20 and 51.70 mbsf.

The younger Miocene planktonic foraminifer assemblages, which are diluted by biosiliceous sediments, primarily contain Globigerina bulloides, G. falconensis, and Globorotalia scitula. Pliocene-Pleistocene assemblages are dominated by Neogloboguadrina pachyderma, with rare occurrences of $G$. bulloides, $G$. falconensis, and Globorotalia puncticulata.

\section{CHRONOSTRATIGRAPHY}

\section{Paleocene/Eocene Boundary}

The planktonic foraminifer datum traditionally used to define the Paleocene/Eocene boundary in tropical to subtropical latitudes is the LAD of Morozovella velascoensis (Berggren and Miller, 1988). However, this species has not been found at Site 738 or other southern middle and high latitude sites (Jenkins, 1971; Stott and Kennett, 1990; Nocchi et al., in press; Berggren, in press b).

Stott and Kennett (1990) correlated the FAD of Planorotalites australiformis with the middle of magnetic polarity Chron $\mathrm{C} 24 \mathrm{~N}$ at ODP Hole 690B and suggested that this datum approximates the Paleocene/Eocene boundary based on the revised paleomagnetic calibrations of Aubrey et al. (1989). Stott and Kennett (1990) also indicated that the FAD of $A$. wilcoxensis berggreni $(=A$. wilcoxensis in this report $)$ is about $58.2 \mathrm{Ma}, 0.4-0.8$ m.y. younger than the FAD of $P$. australiformis. By using Stott and Kennett's approach, the Paleocene/Eocene boundary would approximately correlate with the FAD of $P$ australiformis, between Cores 119-738C-11R and -13R. However, this is below the FAD of $M$. subbotinae, which is used to define the base of the uppermost Paleocene P6a Zone (Berggren and Miller, 1988).

Because of the overlap in taxonomic concepts among several late Paleocene and early Eocene Planorotalites species (see taxonomic discussion), the FAD of $P$. australiformis is not used to define the Paleocene/Eocene boundary at Site 738. Instead, this boundary is placed between the FAD of Acarinina wilcoxensis in Sample 119-738C-10R-CC and the FAD of M. subbotinae in Sample 119-738C-11R-1, 115-118 cm (284.55-283.40 mbsf). Although the first initial occurrence of $M$. subbotinae may be diachronous on the Kerguelen Plateau, the calcareous nannoplankton biostratigraphy of Wei and Thierstein (this volume) is in agreement with placement of the Paleocene/Eocene boundary at this level.

The FAD of Pseudohastigerina wilcoxensis occurs in the uppermost part of Zone P6a in tropical regions, and has been used to approximate the position of the Paleocene/Eocene boundary (Jenkins, 1971; Berggren et al., 1985b). A poorly preserved specimen identified as $P$. wilcoxensis occurs in Sample 119-738B-11R$1,115-118 \mathrm{~cm}$, immediately below the Paleocene/Eocene boundary.

Rare specimens of the benthic foraminifer Gavelinella beccariiformis occur as high as Core 119-738C-9R, although several authors (e.g., Tjalsma and Lohmann, 1983; van Morkhoven et al., 1986; Thomas, 1990) have correlated the LAD of this species with a major deep-sea benthic foraminifer extinction event 
that approximates the P6a/P6b zonal boundary ( = Paleocene/ Eocene boundary). Recognition of this extinction event at Hole $738 \mathrm{C}$ must await a more detailed taxonomic analysis of the benthic foraminifers.

\section{Early/middle Eocene Boundary}

The early/middle Eocene boundary is traditionally identified at the FAD of Hantkenina (= base of Zone P10 of Berggren and Miller; 1988) in tropical and subtropical latitudes. However, this taxon was probably excluded from the southern high latitudes, as it has not been found in the southern South Atlantic region (Stott and Kennett, 1990; Nocchi et al., in press) or at the Kerguelen Plateau (Berggren, in press a; this study). Although Premoli Silva and Boersma (1988) have suggested that the FAD of $P$. micra can be used to identify the base of the middle Eocene, the rare and sporadic occurrence of this species in the lower part of its range makes this approach untenable at the Kerguelen Plateau.

In the absence of diagnostic planktonic foraminifer species, this boundary is placed at about $227 \mathrm{mbsf}$ at the base of calcareous nannoplankton Zone CP12 (Wei and Thierstein, this volume), just above the FAD of $C$. amekiensis.

\section{Middle/late Eocene Boundary}

Identification of the middle/late Eocene boundary at low latitudes has been loosely associated with the final extinction of muricate and subquadrate acarininids, morozovellids, and Planorotalites (Berggren et al., 1985b; Premoli Silva and Boersma, 1988). However, extinction of these groups at the Kerguelen Plateau is graded over a long stratigraphic interval beginning with the LAD of $P$. australiformis (= LAD of Planorotalites spp.) during the early Eocene (185.40-179.70 mbsf) and followed by the middle Eocene LAD's of $A$. spinulosa (= LAD Morozovella spp.; 121.70-118.70 mbsf), A. primitiva (= LAD coarsely muricate acarinids; $74.40-72.90 \mathrm{mbsf}$ ), and $A$. spinuloinflata (= LAD subquadrate acarininids; $61.90-61.00 \mathrm{mbsf}$ ). The latter event (LAD of $A$. spinuloinflata) is coincident with the LAD of S. linaperta s.s. at Site 738.

The LAD of $S$. linaperta s.s. has been correlated with Chron $\mathrm{C} 17 \mathrm{~N}$ at the Maud Rise (Stott and Kennett, 1990) as well as Kerguelen Plateau Site 748 (Berggren, in press a), and is considered here as the best approximation of the late/middle Eocene boundary at Hole 738B.

\section{Eocene/Oligocene Boundary}

The Eocene/Oligocene boundary has been placed in the upper part of Chron 13R and assigned an age of $36.6 \mathrm{Ma}$ (Berggren et al., 1985b). The extinction of Hantkenina spp., Globigerinatheka tropicalis, Pseudohastigerina danvillensis, and Turborotalia cerroazulensis have been used to define this chronostratigraphic boundary at low latitudes (Nocchi et al., 1986; Premoli Silva and Boersma, 1988; Berggren and Miller, 1988), but these marker taxa are rare or absent from the Austral regions (Stott and Kennett, 1990; Nocchi et al., in press; Berggren, in press a; this study). A number of studies based on high resolution ${ }^{87} \mathrm{Sr} /{ }^{86} \mathrm{Sr}$ stratigraphy and magnetobiostratigraphic correlation have demonstrated that the LAD of Globigerinatheka index is synchronous in the Atlantic and Pacific Ocean basins, as well as the Weddell Sea, occurring at about 37.0-37.1 Ma (Berggren et al., 1983, 1985b; Hess et al., 1989). Although this datum precedes the Eocene/Oligocene boundary as recognized Berggren et al. (1985b), it provides the best approximation of this boundary in southern high latitude regions.

At Hole 744A, G. index last occurs between 158.00 and 157.10 mbsf, at the level of a short normal event within Chron $\mathrm{C} 15 \mathrm{~N}-2$ (Fig. 4, Table 5). Based on the magneto- and biochronologic data for Site 744, the age of this datum is estimated as $37.3 \mathrm{Ma}$ and the Eocene/Oligocene boundary is placed at about 148 mbsf (Barron, Baldauf et al., this volume). In the absence of magnetostratigraphic data, this chronostratigraphic boundary is placed at the level of extinction of $G$. index at Hole $738 \mathrm{~B}$, at about $35.65 \mathrm{mbsf}$.

\section{Early/late Oligocene Boundary}

Global synchroneity in the extinction of $C$. cubensis at about $30.0 \mathrm{Ma}$ has been demonstrated by a number of authors (Berggren et al., 1985b; Hess et al., 1989; Stott et al., 1990). This bioevent identifies the base of Zone P21b (Berggren and Miller, 1988) and has been used to mark the boundary between the lower and upper Oligocene at the top of Chron C10N (Berggren et al., 1985b).

At Hole 744A, the late/early Oligocene boundary is placed at the last abundant occurrence of $C$. cubensis between 117.15 and 118.20 mbsf rather than its "absolute" last occurrence several samples higher, as the latter occurrence may be due to reworking. This is less than $2 \mathrm{~m}$ above the LAD of S. angiporoides, which occurs in a reversed polarity interval identified as Chron C11R. The age of the latter datum has been estimated as $32.0 \mathrm{Ma}$ by several authors (Berggren et al., 1985b; Hess et al., 1989; Stott et al., 1990). The close proximity of the $C$. cubensis and $S$. angiporoides LAD's, and apparent absence of Chron $\mathrm{C} 10$ at Hole 744A (Barron, Baldauf, et al., this volume) indicates the presence of a disconformity truncating the uppermost range of $C$. cubensis (Table 3 ).

\section{Oligocene/Miocene Boundary}

The Oligocene/Miocene boundary is placed between Sample $119-744 \mathrm{~A}-11 \mathrm{H}-\mathrm{CC}$ and the top of Core 119-744A-12H ( 99.2 mbsf) based on the calcareous nannofossil biostratigraphy of Wei and Thierstein (this volume). Closely associated with this boundary is the LAD of $G$. euapertura which occurs between 101.66 and 99.20 mbsf in a normal magnetic polarity interval identified as C7AN. Berggren (in press a) found that the extinction of $G$. euapertura occurs at a slightly higher level within Chron $6 \mathrm{CN}$.

\section{SUMMARY AND CONCLUSIONS}

A nearly continuous calcareous biogenic record spanning from the late Maestrichtian through the Cenozoic was recovered from southern Kerguelen Plateau Sites 738 and 744 during ODP Leg 119. The proximity of these sites to the continental margin of East Antarctica makes them ideal for the study of past climatic fluctuations that occurred on the Antarctic continent and in the surrounding surface to intermediate waters.

Biostratigraphic correlation of the Kerguelen Plateau faunas with assemblages recovered from the Weddell Sea was primarily achieved using the Antarctic Paleogene zonal scheme developed by Stott and Kennett (1990). One of these zones was redefined in this study because of discrepancies in the stratigraphic ranges of the original defining taxa. Ages for planktonic foraminifer datum events occurring in the late Eocene-early Miocene interval at Site 744 are calibrated based on the magnetobiochronologic age model of Barron, Baldauf, et al. (this volume), affording a high degree of accuracy in cross-latitude correlation.

Changes in the species composition and taxonomic diversity of planktonic foraminifers from Sites 738 and 744 were strongly influenced by the climatic evolution of Antarctic surface water masses. Early Paleocene assemblages are nearly identical in species composition to coeval lower latitude assemblages, and show the same patterns of post-extinction recovery and taxonomic radiation. By the late early Paleocene, the absence of tropical markers such as "Morozovella" uncinata and $M$. angulata indicates some biogeographic isolation. Kerguelen Plateau surface 
water temperatures were relatively stable throughout the early Paleocene, averaging $12^{\circ}-14^{\circ} \mathrm{C}$ (Barrera and Huber, this volume).

Increased provincialism is apparent in late Paleocene assemblages with the absence of a number of large keeled morozovellid and planorotalitid taxa that characterize tropical regions. Although surface water temperatures did not change from the early Paleocene values, intermediate waters either cooled or became more saline (Barrera and Huber, this volume).

A high latitude incursion of tropical keeled morozovellids ( $M$. subbotinae and $M$. gracilis) occurred during the latest Paleocene and earliest Eocene as the diversity of acarininids rapidly increased. Maximum planktonic foraminifer diversity ( 23 species) was achieved during the early Eocene at a time when near-surface and intermediate water temperatures reached their Cenozoic maximum. Oxygen isotope estimates for this time indicate peak nearsurface temperatures of $18^{\circ} \mathrm{C}$ for acarininids and $16^{\circ} \mathrm{C}$ for subbotinids (Barrera and Huber, this volume).

A gradual decline in species diversity from late early through middle Eocene time, primarily due to the extinction of acarininids, parallels a pattern of cooling paleotemperatures in high latitude surface waters (Stott et al., 1990; Barrera and Huber, this volume) and increased latitudinal thermal contrasts (Shackleton and Boersma, 1981; Boersma et al., 1987). Estimated near-surface water temperatures at the Kerguelen Plateau dropped to about $11^{\circ} \mathrm{C}$ by the end of the middle Eocene (Barrera and Huber, this volume). By late middle Eocene time, the planktonic assemblages were dominated by Globorotaloides, Globigerinatheka, and especially Chiloguembelina. A late middle Eocene increase in chiloguembelinid abundance has also been recognized at high latitude sites in the Atlantic Ocean (Boersma et al., 1987).

Late Eocene and early Oligocene assemblages exhibit considerably lower diversity than the older Eocene faunas, and were dominated by Chiloguembelina, Subbotina, Catapsydrax, and, until the end of the Eocene, Globigerinatheka. Catapsydrax unicavus, Subbotina utilisindex, and S. angiporoides increased in abundance during the latest Eocene and early Oligocene as near surface water temperatures cooled from about $11^{\circ} \mathrm{C}$ to about $6^{\circ} \mathrm{C}$ (Barrera and Huber, this volume). Ice-rafted debris occurs in sediments that were deposited during this rapid cooling event, indicating that continental glaciers had reached the coastal margins of Antarctica by earliest Oligocene time.

Globigerinita juvenilis replaced Chiloguembelina cubensis as the dominant planktonic foraminifer in late Oligocene assemblages, while catapsydracids, globigerinids, and globorotaloids occurred in lower numbers. Diversity increased slightly toward the end of the Oligocene with new appearances of several tenuitellid, globoturborotalitiid, and globigerinid species. This corresponds with a slight warming of near-surface water temperatures at the Kerguelen Plateau (Barrera and Huber, this volume).

The trend toward diminishing planktonic foraminifer diversity was renewed during the late early Miocene as siliceous productivity increased in the Antarctic surface waters and near-surface water temperatures further diminished. This trend culminated by the beginning of the Pliocene with the occurrence of nearly monospecific assemblages of Neogloboquadrina pachyderma.

\section{SPECIES LIST AND TAXONOMIC NOTES}

Paleogene planktonic foraminifer species included in the distribution charts for Sites 738 and 744 (Tables 1-3) are listed in alphabetical order below. Most of the Danian species in this list are illustrated in a separate report (Huber, this volume). Comments are included for several species to clarify my taxonomic concepts and to discuss distinguishing morphologic features of indeterminate species. All illustrated specimens are stored in the U.S. National Museum and are catalogued according to the numbers listed below.
Acarinina acarinata Subbotina, 1953: PI. 1, Figs. 11, 12, 16 (USNM 449841).

Acarinina aculeata (Jenkins) 1966

Acarinina broedermanni (Cushman and Bermüdez) 1949: Pl. 3, Fig. 5 (USNM 449842).

Acarinina bullbrooki (Bolli) 1957: Pl. 3, Figs. 6, 7 (USNM 449843).

Acarinina chascanona (Loeblich and Tappan) 1957: Pl. 2, Fig. 3 (USNM 415753); Pl. 2, Fig. 4 (USNM 449844).

Acarinina coalingensis (Cushman and Hanna) 1927: Pl. 3, Fig. 2 (USNM 449845). This species morphologically overlaps with early Eocene forms of Acarinina primitiva, but is distinguished by having a more coarsely muricate surface ornamentation and a more irregular arrangement of the final whorl chambers.

Acarinina collactea (Finlay) 1939: Pl. 3, Figs. 16, 17 (USNM 449846).

Acarinina cf. A. collactea (Jenkins) 1966: Pl. 3, Figs. 8-10 (USNM 449847). This form differs from $A$. collactea by having a more angular peripheral margin, less inflated chambers, and a more flattened spiral side, and by lacking an umbilicus. Specimens generally have $4.5-5$ chambers in the final whorl and range from $200-400 \mu \mathrm{m}$ in size. Specimens with less angular peripheral margins morphologically intergrade with $A$. collactea.

Acarinina cuneicamerata (Blow) 1979: Pl. 3, Fig. 15 (USNM 449848).

Acarinina esnaensis (LeRoy) 1953: Pl. 1, Figs. 13-15 (USNM 449849).

Acarinina intermedia Subbotina, 1953: Pl. 2, Figs. 19, 20 (USNM 449850).

Acarinina interposita Subbotina, 1953: Pl. 2, Figs. 13-15 (USNM 449851).

Acarinina matthewsae Blow, 1979: Pl. 3, Figs. 3, 4 (USNM 449852).

Acarinina mckannai (White) 1928: Pl. 1, Fig. 20 (USNM 449853).

Acarinina cf. A. mckannai (White) 1952: Pl. 1, Figs. 8-10 (USNM 449854). These forms differ from $A$. soldadoensis by have five rather than four chambers in the final whorl and a higher axis of coiling. Acarinina mckannai has more chambers in the final whorl and a more compact test than $A$. cf. A. mckannai.

Acarinina nitida (Martin) 1943: Pl. 3, Figs. 13, 14 (USNM 449855).

Acarinina pentacamerata (Subbotina) 1936: Pl. 2, Figs. 6-8 (USNM 449856).

Acarinina praeangulata Blow, 1979: Pl. 1, Figs. 6, 7 (USNM 449857).

Acarinina praecursoria Morozova, 1957: PI. 1, Figs. 3-5 (USNM 449858).

Acarinina praepentacamerata Schutzkaya, 1956: Pl. 2, Figs. 1, 2 (USNM 449859).

Acarinina primitiva (Finlay) 1947: P1. 3, Fig. 1 (USNM 449860).

Acarinina pseudotopilensis Subbotina, 1953: Pl. 1, Figs. 17-19 (USNM 449861).

Acarinina soldadoensis (Brönnimann) 1952: Pl. 2, Fig. 16 (USNM 449862).

Acarinina spinuloinflata (Bandy) 1949: Pl. 3, Figs. 11, 12 (USNM 449863).

Acarinina strabocella (Loeblich and Tappan) 1957: Pl. 2, Figs. 11, 12 (USNM 449864).

Acarinina triplex Subbotina, 1953: Pl. 2, Figs. 17, 18 (USNM 449865). Acarinina wilcoxensis (Cushman and Ponton) 1932: Pl. 2, Figs. 5, 9, 10 (USNM 449866). The taxonomic distinction between forms included in $A$. wilcoxensis berggreni Blow and $A$. wilcoxensis wilcoxensis is not clear among the Site 738 populations, and therefore, these subspecies are not differentiated.

Acarinina? sp.: Pl. 1, Figs. 1, 2 (USNM 449867). These middle Paleocene taxa clearly display muricae and are thus distinguished from middle Paleocene subbotinids.

Bifarina alabamensis (Cushman) 1940.

Cassigerinelloita amekiensis (Stolk) 1965: Pl. 7, Fig. 11 (USNM 449868). This distinctive species has a short stratigraphic range, occurring in low abundance within the uppermost lower Eocene at Site 738 and high abundance near the top of its range in lower middle Eocene samples. Cassigerinelloita amekiensis appears to be a good high latitude marker for the lower middle Eocene, as it is restricted to that interval at Kerguelen Plateau Hole 749B (Li Qianyu and Radford, in press) and Leg 114 sites in the subantarctic South Atlantic (Nocchi et al., in press).

Catapsydrax dissimilis (Cushman and Bermúdez) 1937: Pl. 5, Fig. 19 (USNM 449869).

Catapsydrax echinatus Bolli, 1957: PI. 5, Fig. 17 (USNM 449870); Pl. 5, Fig. 20 (USNM 449871).

Catapsydrax unicavus Bolli, Loeblich and Tappan, 1957: Pl. 5, Fig. 18 (USNM 449872). 
Chiloguembelina crinita (Glaessner) 1937: Pl. 6, Figs. 2-3 (USNM 449873).

Chiloguembelina cubensis (Palmer) 1934: Pl. 6, Fig. 8 (USNM 449874). Chiloguembelina morseri (Klein) 1943: Pl. 6, Figs. 6-7 (USNM 449875).

Chiloguembelina wilcoxensis (Cushman and Ponton) 1932: Pl. 6, Figs. 4, 5 (USNM 449876).

Eoglobigerina eobulloides (Morozova) 1959.

Eoglobigerina quadrilocula (Blow) 1979.

Eoglobigerina simplicissima Blow, 1979.

Globigerina bulloides d'Orbigny, 1826.

Globigerina euapertura Jenkins, 1960: Pl. 5, Fig. 7 (USNM 449877).

Globigerina falconensis Blow, 1959.

Globigerina leroyi Blow and Banner, 1962: Pl. 5, Fig. 10 (USNM 449878).

Globigerina praebulloides Blow, 1959.

"Globigerina" cf. G. praebulloides Blow, 1959. This form has a higher spire and lower umbilical apertural arch than typical G. praebulloides.

Globigerina tapuriensis Blow and Banner, 1962.

Globigerinatheka barri Brönnimann, 1952: Pl. 7, Fig. 16 (USNM 449879).

Globigerinatheka index (Finlay) 1939: P1. 7, Fig. 17 (USNM 449880). Globigerinita juvenilis (Egger) 1893.

Globoconusa daubjergensis (Brönnimann) 1953.

Globorotalia puncticulata (Deshayes) 1832.

Globorotalia praescitula Blow, 1959.

Globorotalia scitula (Brady) 1882.

Globorotalia zealandica Hornibrook, 1958.

Globorotaloides suteri Bolli, 1957: Pl. 7, Fig. 18 (USNM 449881),

Globorotaloides aff. G. testarugosa (Jenkins) 1960: Pl. 7 Figs. 19, 20 (USNM 449882). The Kerguelen Plateau forms differ from $G$. testarugosa by have a more compressed test and five rather than four chambers in the final whorl. They strongly resemble specimens of $G$. aff. testarugosa figured by Stott and Kennett (1990).

Globoturborotalita brazieri Jenkins, 1966: Pl. 5, Fig. 9 (USNM 449883). This species is characterized by having a trilobate adult test shape and a highly arched aperture that is centered over the penultimate-antepenultimate chamber suture. The aperture of the figured specimen is not as highly arched as Jenkins' figured types, and a bordering rim is not as well-developed. This species was identified in upper Oligocene-lowermost Miocene samples from Hole 744A, whereas its range is reported as lower Miocene in New Zealand (Jenkins, 1966) and upper Oligocene-lower Miocene at Leg $120 \mathrm{Hole}$ $748 \mathrm{~B}$ (Berggren, in press b) and Leg 114 Hole 703A (Nocchi et al., in press).

Globoturborotalita connecta (Jenkins) 1964.

Globoturborotalita labiacrassata (Jenkins) 1966: Pl. 5, Fig. 16 (USNM 449884).

Globoturborotalita cf. G. labiacrassata (Jenkins) 1966. Forms included in this taxon are relatively large with four strongly inflated chambers in the final whorl and a highly arched aperture bordered by a thickened rim. They are separated from $G$. labiacrassata because of their more strongly inflated chambers and stratigraphic separation from G. labiacrassata. Berggren (in press b) has identified this morphotype in lower Miocene samples from Leg 120 Holes 747A, 748B, and $751 \mathrm{~A}$.

Globoturborotalita woodi(Jenkins) 1960.

Guembilitria triseriata (Terquem) 1882: Pl. 6, Fig. 1 (USNM 449885). This species is restricted to lower middle Eocene sediments at Hole $738 \mathrm{~B}$.

Guembelitrioides sp.: Pl. 4, Figs. 13-15 (USNM 449886). The Kerguelen Plateau forms resemble specimens of $S$. hornibrooki illustrated by Blow (1979), but are distinguished because of their higher spire and presence of supplementary apertures on the spiral side. Early forms of this taxon intergrade with specimens referred to as Subbotina trivialis (see Huber, this volume, Pl. 3, Figs. 16, 17).

Igorina pusilla (Bolli) 1957: Pl. 3, Figs. 18, 19 (USNM 449887).

Igorina spiralis (Bolli) 1957: Pl. 3, Fig. 20 (USNM 449888). This species is rare in upper lower-lower upper Paleocene sediments at Hole 738C. Recognition of $I$. spiralis in lower Danian sediments at Maud Rise Sites 689 and 690 (Stott and Kennett, 1990) is probably based on incorrect identification of this species.

"Morozovella" inconstans (Subbotina) 1953.

Morozovella spinulosa (Cushman) 1927: Pl. 4, Figs. 3, 4 (USNM 449889).

Morozovella gracilis (Bolli) 1957: Pl. 4, Fig. 8 (USNM 449890).
Morozovella cf. M. quetra (Bolli) 1957: Pl. 4, Figs. 5, 10 (USNM 449891). The peripheral keel of these forms is not as well-developed as on low latitude forms of $M$. quetra.

Morozovella subbotinae (Morozova) 1939: Pl. 4, Fig. 9 (USNM 449892).

Muricoglobigerina senni (Beckmann) 1953: Pl. 7, Fig. 21 (USNM 449893).

Neogloboguadrina pachyderma (Blow) 1959.

Paragloborotalia nana (Bolli) 1957: Pl. 7, Fig. 15 (USNM 449894).

Paragloborotalia pseudocontinuosa Jenkins) 1967: Pl. 7, Figs. 13, 14 (USNM 449895). This species is distinguished from $P$. nana by having a more highly arched aperture, but both species have a thickened lip bordering the aperture and four chambers in the final whorl (e.g., see Jenkins and Srinivasan, 1985). Occurrence of this species in upper Eocene sediments at Sites 738 and 744 is contrary to the generally recognized lower Miocene range at mid latitude sites (Jenkins, 1967; Jenkins and Srinivasan, 1985), but is consistent with its distribution at subantarctic Leg 114 sites in the South Atlantic (Nocchi et al., in press).

Paragloborotalia incognita (Walters) 1965.

Planorotalites australiformis Jenkins, 1966: Pl. 6, Figs. 17, 18 (USNM 449896). Forms with a rounded equatorial periphery and 4 to 4.5 chambers in the final whorl are included in $P$. australiformis.

Planorotalites cf. P. appressus (Blow) 1979.

Planorotalites chapmani (Parr) 1938: Pl. 6, Figs. 19, 20 (USNM 449897).

Planorotalites compressus (Plummer) 1926.

"Planorotalites" imitatus (Subbotina) 1953: PI. 6, Figs. 21, 22 (USNM 449898).

Planorotalites planoconicus (Subbotina) 1953: Pl. 6, Figs. 15, 16 (USNM 449899). Specimens included in this species are smaller and more elongate than $P$. pseudomenardii and lack a well-defined keel. The taxonomic distinctions between $P$. pseudomenardii, $P$. australiformis, and P. planoconicus varies between different authors because of the occurrence of intergrading forms (Tjalsma, 1977).

"Planorotalites" reissi (Loeblich and Tappan) 1957: Pl. 4, Figs. 18-20 (USNM 4498100).

Planorotalites sp. 2: Pl. 6, Figs. 23, 24 (USNM 449901). The tests of these taxa are moderately compressed and evolute on the umbilical side, they have six chambers in the final whorl. Praetenuitella insolita (Jenkins) 1966: PI. 7, Figs. 9, 10 (USNM 449902).

Praetenuitella sp. 1: Pl. 6, Figs. 25, 26 (USNM 449903). These middle Eocene forms generally have five broadly rounded chambers in the final whorl and an umbilical-extra-umbilical aperture.

Praetenuitella sp. 2: Pl. 7, Figs. 3, 4 (USNM 449904). The test of these forms are more laterally compressed and broadly evolute than $T e$ nuitella gemma, and they have six to seven rather than five chambers in the final whorl. It more closely resembles Praetenuitella sp. 3, but has fewer chambers.

Praetenuitella sp. 3: Pl. 7, Figs. 1, 2 (USNM 449905). This distinctive taxon is distinguished from Praetenuitella sp. 2 by having seven to eight rather than six to seven chambers in the final whorl and a higher axis of coiling.

Pseudohastigerina micra (Cole) 1927: PI. 6, Figs. 13, 14 (USNM 449906).

Pseuodohastigerina wilcoxensis (Cushman and Ponton) 1932: Pl. 6, Figs. 9,10 (USNM 449907). The edge view of the figured specimen shows slight asymmetry in the position of the aperture, as is characteristic of the earliest forms in the evolutionary transition of this species from $P$. champmani (see Blow, 1979).

Pseudohastigerina sp.: Pl. 6, Figs. 11, 12 (USNM 449908). This taxon occurs much stratigraphically higher than $P$. wilcoxensis and is more rounded in its equatorial periphery.

Sphaeroidinellopsis cf. S. disjuncta (Finlay) 1940.

Subbotina angiporoides (Hornibrook) 1965: Pl. 5, Fig. 5 (USNM 449909).

Subbotina brevis (Jenkins) 1966: Pl. 5, Fig. 8 (USNM 449923). Rare specimens of this species occur in several samples near the Eocene/ Oligocene boundary at Sites 738 and 744 .

Subbotina corpulenta Subbotina, 1953.

Subbotina eocaena (Guembel) 1868: Pl. 5, Fig. 13 (USNM 449910).

Subbotina gortanii (Borsetti) 1959: Pl. 5, Figs. 14, 15 (USNM 449911).

Subbotina hardingae (Blow) 1979: Pl. 5, Fig. 4 (USNM 449912).

Subbotina cf. S. hornibrooki (Brönnimann) 1952. Specimens included in this taxon generally have 3.5 rather than 4 chambers in the final whorl and a higher axis of coiling.

Subbotina linaperta (Finlay) 1939: Pl. 5, Fig. 1 (USNM 449913). Forms included in this species have a lobate peripheral outline with three 
chambers in the final whorl. Specimens referable as $S$. linaperta s.s. are distinguished from $S$. linaperta s.l. by having greater axial flattening of the ultimate whorl chambers, an ultimate chamber that comprises a greater proportion (nearly one-half) of the final whorl, and a more highly arched aperture.

Subbotina patagonica (Todd and Knicker) 1952: Pl. 4, Figs. 16, 17 (USNM 449914).

Subbotina pseudobulloides (Plummer) 1926.

Subbotina pseudoeocaena Subbotina, 1953: Pl. 5, Fig. 2 (USNM 449915).

Subbotina pseudovenezuelana Blow and Banner, 1962: Pl. 5, Fig. 11 (USNM 449916).

Subbotina triangularis (White) 1928.

Subbotina triloculinoides (Plummer) 1926.

Subbotina trivialis (Subbotina) 1955.

Subbotina utilisindex (Jenkins and Orr) 1973: Pl. 5, Fig. 6 (USNM 449917). Late Eocene forms included in this taxon show morphologies that intergrade with the morphology of Subbotina linaperta linaperta. They are distinguished by having a broader, low-arched aperture, and final whorl chambers that are more equidimensional.

Subbotina varianta (Subbotina) 1953: Pl. 4, Figs. 6, 7 (USNM 449918)

Subbotina velascoensis (Cushman) 1925: Pl. 4, Figs. 11, 12 (USNM 449919).

Subbotina yeguaensis Weinzierl and Applin, 1929.

Tenuitella angustiumbilicata Bolli, 1957: Pl. 7, Figs. 6, 12 (USNM 449920).

Tenuitella clemenciae (Bermudez) 1961.

Tenuitella gemma (Jenkins) 1966: Pl. 7, Figs. 7, 8 (USNM 449921).

Tenuitella munda (Jenkins) 1966: P1. 7, Fig. 5 (USNM 449922).

Turoborotalia quinqueloba Natland, 1938.

Zeauvigerina teuria Finlay, 1947.

\section{ACKNOWLEDGMENTS}

I thank the captains and crew of the JOIDES Resolution and Maersk Master, and particularly John Barron, Birger Larsen (Co-Chief Scientists), Jack Baldauf (Staff Scientist) and the ODP technical staff for an enjoyable and very successful cruise. I am also grateful to Lowell Stott, William A. Berggren, D. Graham Jenkins, and Richard K. Olsson for their comments on various aspects of the Paleogene planktonic foraminifer taxonomy, and Anne Boersma and Lowell Stott for reviewing this manuscript and offering a number of helpful suggestions. I am indebted to Elisabeth Valiulis for her dedicated assistance in preparation of the figures, tables, and plates. I especially owe thanks to Kathleen Mullaney Huber for tolerating my absence during the early and late phases of this study.

\section{REFERENCES}

Aubry, M.-P., Berggren, W. A., Kent, D. V., Flynn, J. J., Klitgord, K. D., Obradovich, J. D., and Prothero, D. R., 1988. Paleogene geochronology: an integrated approach. Paleoceanography, 3:707742.

Barrett, P. J. (Ed.), 1989. Antarctic Cenozoic history from the CIROS-1 drillhole, McMurdo Sound. DSIR Bull., 245.

Barron, J., Larsen, B., et al., 1989. Proc. ODP, Init. Repts., 119: College Station, TX (Ocean Drilling Program).

Berggren, W. A., 1969. Rates of evolution in some Cenozoic planktonic foraminifera. Micropaleontology, 15:351-365.

in press a. Paleogene planktonic foraminifer magneto-biostratigraphy of the southern Kerguelen Plateau (ODP Sites 747-749). In Schlich, R., Wise, S. W., Jr., et al., Proc. ODP, Sci, Results, 120: College Station, TX (Ocean Drilling Program).

in press b. Neogene planktonic foraminifer magnetobiostratigraphy of the southern Kerguelen Plateau (ODP Sites 747, 748, and 751). In Schlich, R., Wise, S. W., Jr., et al., Proc. ODP, Sci. Results, 120: College Station, TX (Ocean Drilling Program).

Berggren, W. A., Aubry, M.-P., and Hamilton, N., 1983. Neogene magnetostratigraphy of Deep Sea Drilling Project Site 516 (Rio Grande Rise, South Atlantic). In Barker, P. F., Carlson, R. L., Johnson, D. A., et al., Init. Repts. DSDP, 72: Washington (U.S. Govt. Printing Office), 675-713.

Berggren, W. A., Kent, D. V., and Flynn, J. J., 1985a. Jurassic to Paleogene: Part 2. Paleogene geochronology and chronostratigraphy. In
Snelling, N. J. (Ed.), The Chronology of the Geological Record. Geol. Soc. London Mem., 10:141-195.

Berggren, W. A., Kent, D. V., and Van Couvering, J. A., 1985b. The Neogene: Part 2. Neogene geochronology and chronostratigraphy. In Snelling, N. J. (Ed.), The Chronology of the Geological Record. Geol. Soc. London Mem., 10:211-260.

Berggren, W. A., and Miller, K. G., 1988. Paleogene tropical planktonic foraminiferal biostratigraphy and magnetobiochronology. Micropaleontology, 34:362-380.

Blow, W. H., 1969. Late middle Eocene to Recent planktonic foraminiferal biostratigraphy. In Brönniman, P., and Renz, H. H., (Eds.), Proc. First Intern. Conf. Planktonic Microfossils, Geneva: Leiden (E. J. Brill), 1:199- 422. 1979. The Cainozoic Globigerinida: Leiden (E. J. Brill).

Boersma, A., and Premoli Silva, I., 1989. Atlantic Paleogene biserial heterohelicids and oxygen minima. Paleoceanography, 4:271-286.

Boersma, A., Premoli Silva, I., and Shackleton, N. J., 1987. Atlantic Eocene planktonic foraminiferal paleohydrographic indicators and stable isotope paleoceanography. Paleoceanography, 2:287-331.

Bolli, H. M., 1957. The genera Globigerina and Globorotalia in the Paleocene-lower Eocene Lizard Springs Formation of Trinidad, B. W. I. Bull. U.S. Nat. Mus., 215:97-124.

Cifelli, R., and Scott, G. H., 1983. The New Zealand early Miocene globorotaliids Globorotalia incognita Walters and Globorotalia zealandica Hornibrook. J. Foraminiferal Res., 13:163-166.

Hess, J., Stott, L. D., Bender, M. L., Kennett, J. P., and Schilling, J.-G., 1990. The Oligocene marine microfossil record: age assessments using strontium isotopes. Paleoceanography, 4:655-679.

Jenkins, D. G., 1966. Planktonic foraminiferal zones and new taxa from the Danian to Lower Miocene of New Zealand. N. Z. J. Geol. Geophys., 8:1088-1126.

1967. Planktonic foraminiferal zones and new taxa from the lower Miocene to the Pleistocene of New Zealand. N. Z. J. Geol. Geophys., 10:1064-1078.

1971. New Zealand Cenozoic planktonic foraminifera. N. Z. Dept. Sci. Industr. Res., N. Z. Geol. Surv., Paleontol. Bull., 42:1178.

Jenkins, D. G., and Srinivasan, M. S., 1986. Cenozoic planktonic foraminifers from the equator to the subantarctic of the southwest $\mathrm{Pa}$ cific. In Kennett, J. P., von der Borch, C. C., et al., Init. Repts. DSDP, 90: Washington (U.S. Govt. Printing Office), 795-834.

Li Qianyu and Radford, S. S., in press. Morphology and affinity of the planktonic foraminifer Cassigerinelloita amekiensis Stolk and reclassification of Cassigerinelloita Stolk. In Schlich, R., Wise, S. W., Jr., et al., Proc. ODP, Sci. Results, 120: College Station, TX (Ocean Drilling Program).

Loeblich, A., and Tappan, H., 1987. Foraminiferal Genera and Their Classification: New York (Van Nostrand).

Loeblich, A. R., Jr., and Tappan, H., 1957. Planktonic foraminifera of Paleocene and early Eocene age from the Gulf and Atlantic Coastal Plains. Bull. U.S. Nat. Mus., 215:173-198.

Nocchi, M., Amici, E., and Premoli Silva, I., in press. Planktonic foraminiferal biostratigraphy and paleoenvironmental interpretation of Paleogene sediments from Subantarctic Transect, ODP Leg 114. In Ciesielski, P. F., Kristoffersen, Y., et al., Proc. ODP, Sci. Results, 114: College Station, TX (Ocean Drilling Program).

Nocchi, M., Parisi, G., Monaco, P., Monechi, S., Madile, M., Napoleone, G., Ripepe, M., Orlando, M., Premoli Silva, I., and Rice, D. M., 1986. The Eocene-Oligocene boundary in the Umbrian pelagic sequences. In Pomerol, C., and Premoli Silva, I. (Eds.), Terminal Eocene Events: New York (Elsevier), 25-40.

Premoli Silva, I., and Boersma, A., 1988. Atlantic Eocene planktonic foraminiferal historical biogeography and paleohydrographic indices. Palaeogeogr., Palaeoclimatol., Palaeoecol., 67:315-356.

Shackleton N. J., and Boersma, A., 1981. The climate of the Eocene ocean. J. Geol. Soc. London, 138:153-157.

Stott, L. D., and Kennett, J. P., 1990. Antarctic Paleogene planktonic foraminifer biostratigraphy: ODP Leg 113, Sites 689 and 690. In P. F. Barker, J. P. Kennett, and et al., Proc. ODP, Sci. Results, 113: College Station, TX (Ocean Drilling Program), 549-569.

Stott, L. D., Kennett, J. P., Shackleton, N. J., Corfield, R. M., 1990. The evolution of Antarctic surface waters during the Paleogene: inferences from stable isotopic composition of planktonic foraminifers, ODP Leg 113. In Barker, P. F., Kennett, J. P., et al., Proc. 
ODP, Sci. Results, 113: College Station, TX (Ocean Drilling Program), 849-863.

Subbotina, N. N., 1953. Fossil Foraminifera of the USSR: Globigerinidae, Hantkeninidae and Globorotalidae: London and Wellingborough (Collet's Ltd.). E. Lees, (Trans.)

Thomas, E., 1990. Late Cretaceous through Neogene deep-sea benthic foraminifers (Maud Rise, Weddell Sea, Antarctica). In Barker, P. F., Kennett, J. P., et al., Proc. ODP, Sci. Results, 113: College Station, TX (Ocean Drilling Program), 571-594.

Tjalsma, R. C., 1977. Cenozoic foraminifera from the South Atlantic, DSDP Leg 36. In Barker, P., Dalziel, I.W.D., et al., Init. Repts. DSDP, 36: Washington (U.S. Govt. Printing Office), 493-517.
Tjalsma, R. C., and Lohmann, G. P., 1983. Paleocene-Eocene bathyal and abyssal benthic foraminifera from the Atlantic Ocean. Micropaleontol. Spec. Publ: 4:1-90.

van Morkhoven, F.P.C.M., Berggren, W. A., and Edwards, A. S., 1986. Cenozoic cosmopolitan deep-water benthic foraminifera. Bull. Cent. Rech. Explor.-Prod. Elf-Aquitaine, Mem. 11.

Date of initial receipt: 22 January 1990

Date of acceptance: 5 July 1990

Ms 119B-142 

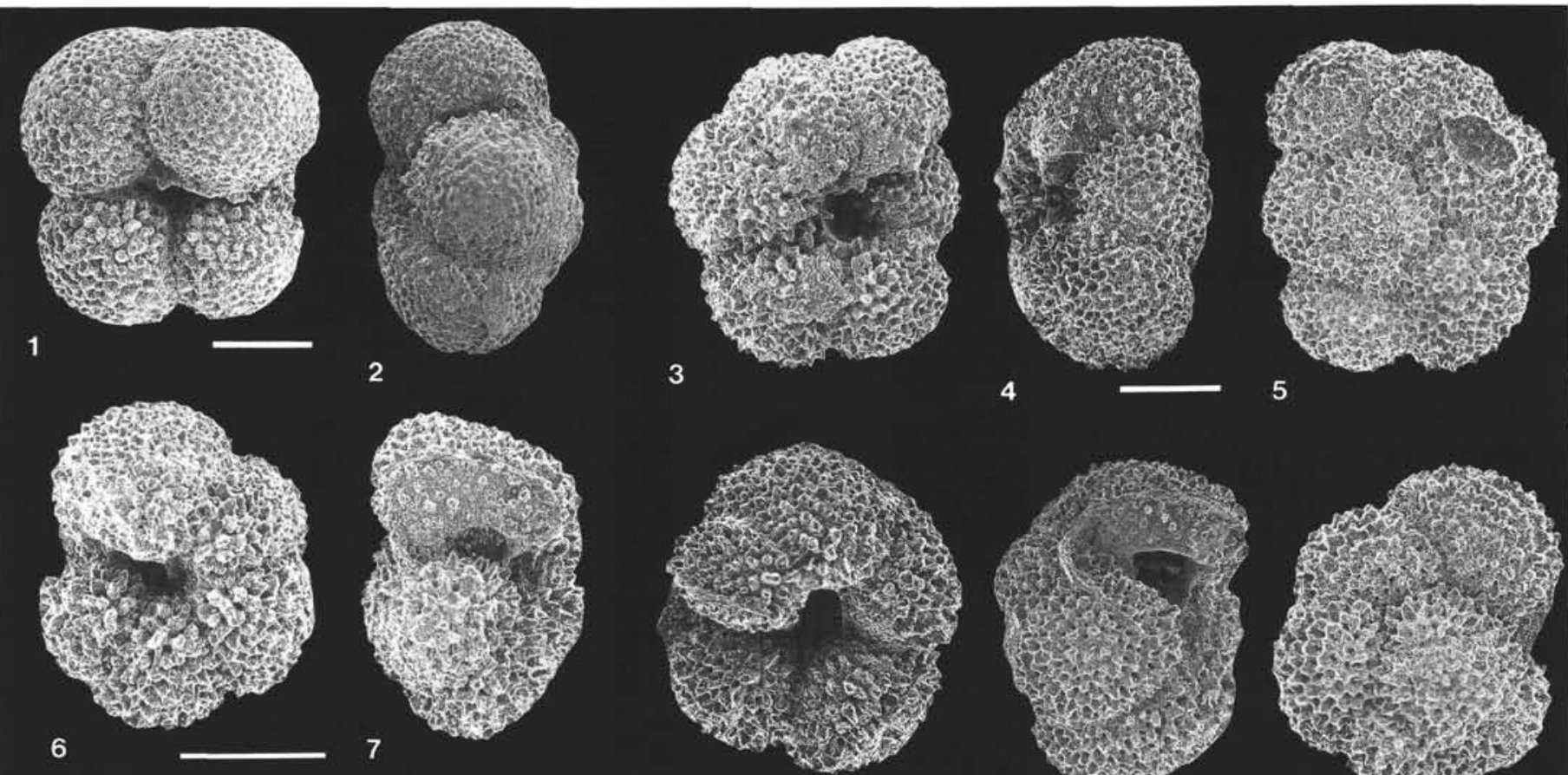

8
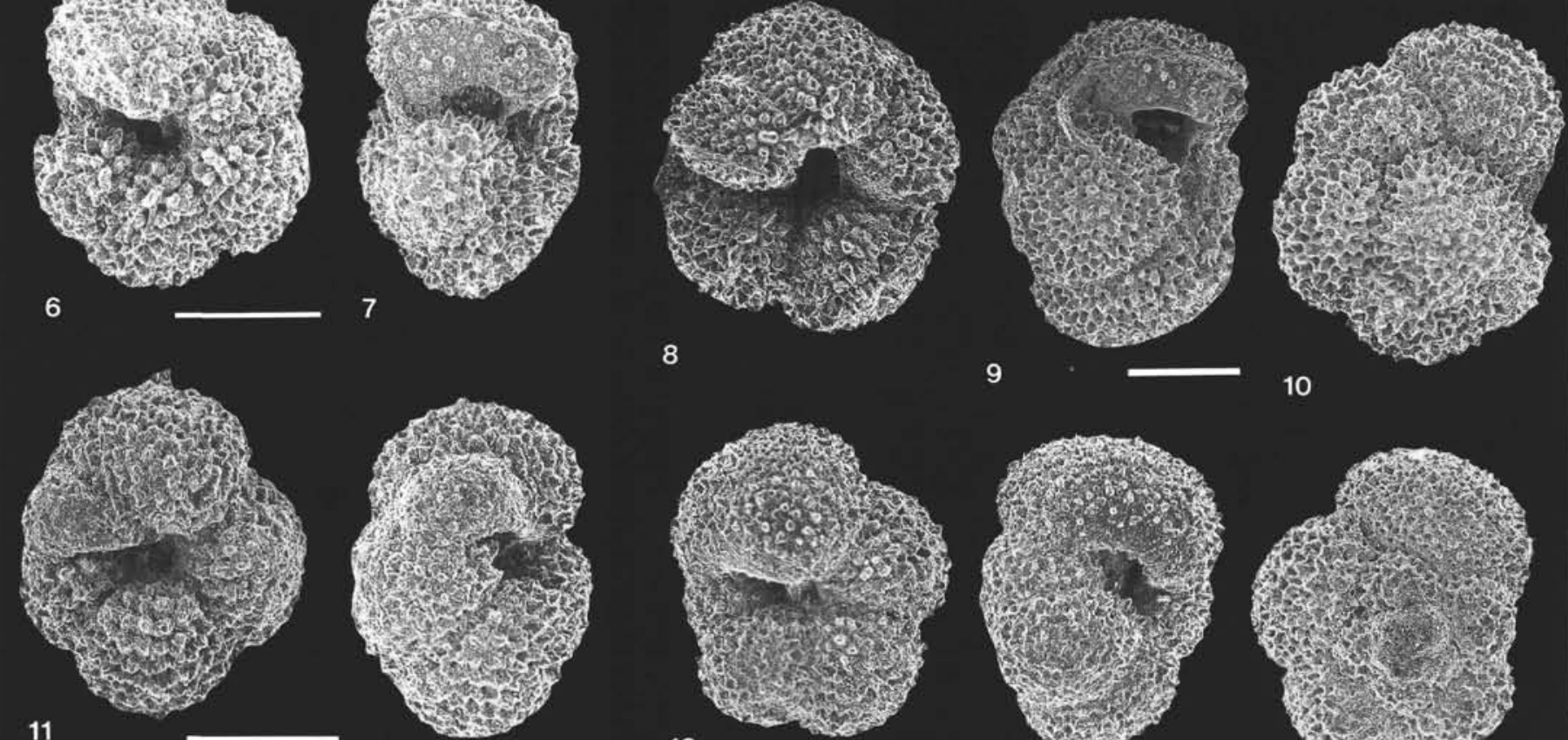

12
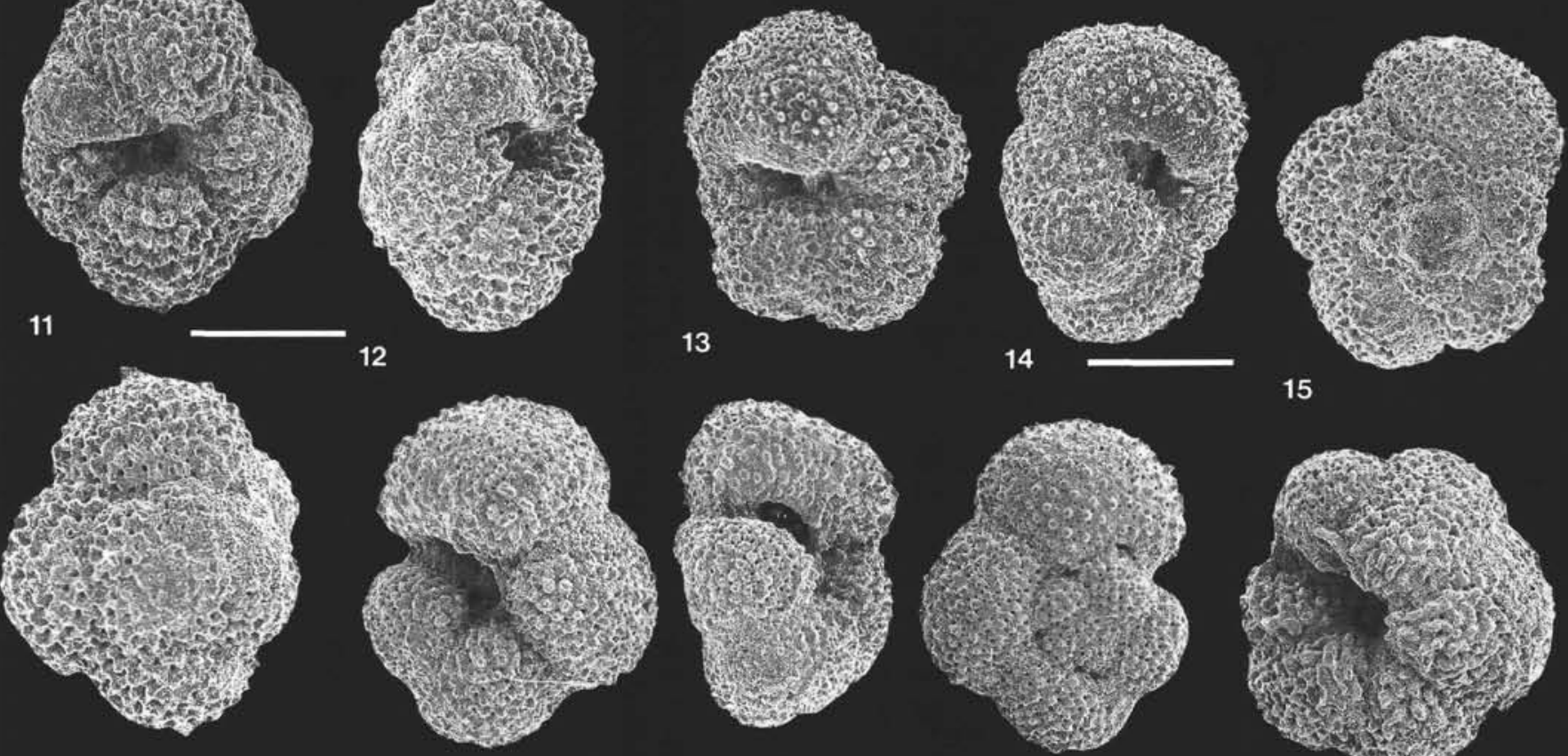

18

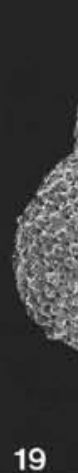

15
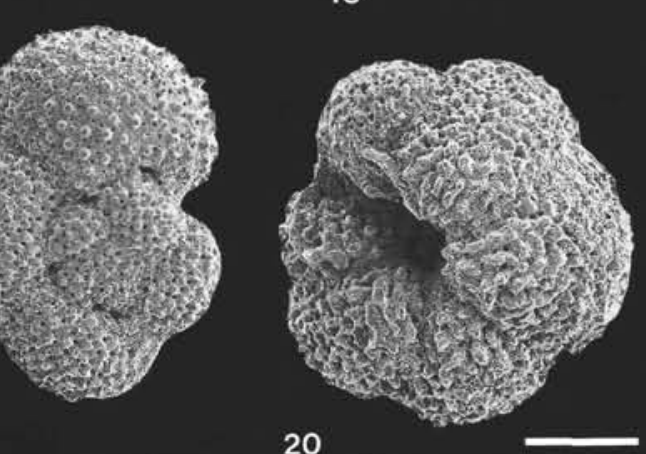

Plate 1. Late Paleocene planktonic foraminifers recovered from Hole 738C. Scale bars for all figures represent $100 \mu \mathrm{m}$. 1, 2. Acarinina? sp. (332.15 mbsf), (1) ventral view, (2) edge view. 3-5. Acarinina praecursoria (332.15 mbsf), (3) ventral view, (4) edge view, (5) dorsal view. 6, 7. Acarinina praeangulata (332.15 mbsf), (6) ventral view, (7) edge view. 8-10. Acarinina $\mathrm{cf}$. A. mckannai (286.05 mbsf), (8) ventral view, (9) edge view, (10) dorsal view. 11, 12, 16. Acarinina acarinata (277.78 mbsf), (11) ventral view, (12) edge view, (16) dorsal view. 13-15. Acarinina esnaensis (332.15 mbsf), (13) ventral view, (14) edge view, (15) dorsal view. 17-19. Acarinina pseudotopilensis (277.78 mbsf), (17) ventral view, (18) edge view, (19) dorsal view. 20. Acarinina mckannai (332.15 mbsf). 

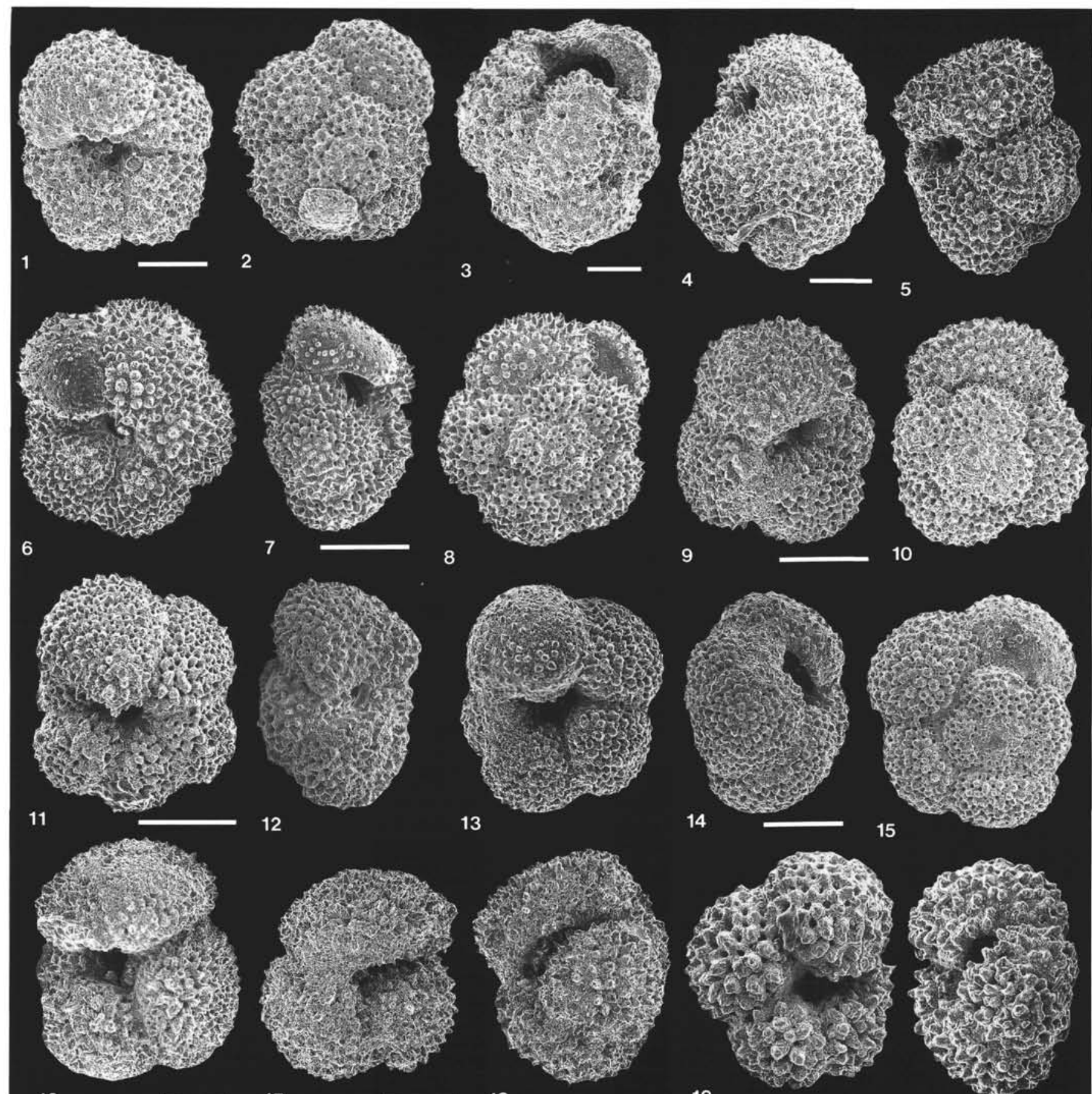

12
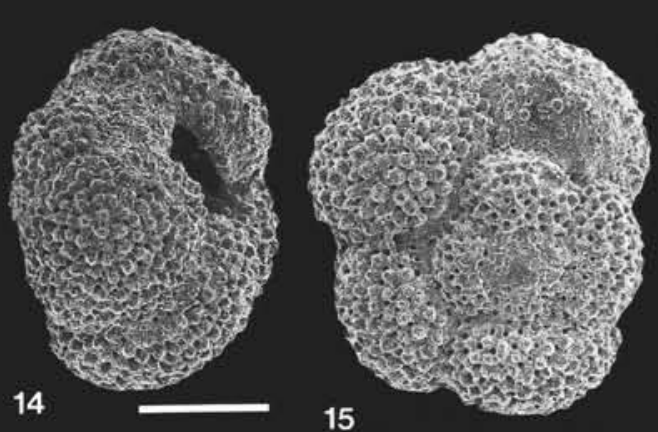

16
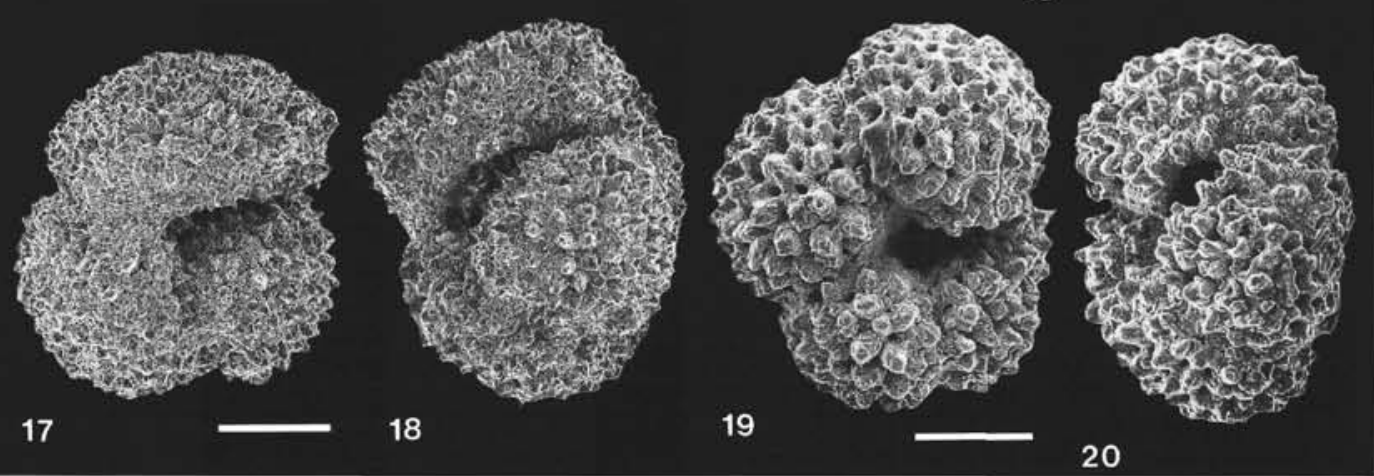

Plate 2. Late Paleocene-early Eocene acarininid foraminifers recovered from Hole 738C. Scale bars for all figures represent $100 \mu \mathrm{m}$. 1, 2. Acarinina praepentacamerata (286.05 mbsf), (1) ventral view, (2) dorsal view. 3. Acarinina chascanona (322.07 mbsf). 4. Acarinina chascanona (236.04 mbsf). 5, 9, 10. Acarinina wilcoxensis ( $245.68 \mathrm{mbsf})$, (5) edge view, (9) ventral view, (10) dorsal view. 6-8. Acarinina pentacamerata (206.79 mbsf), (6) ventral view, (7) edge view, (8) dorsal view). 11, 12. Acarinina strabocella (275.25 mbsf), (11) ventral view, (12) edge view. 13-15. Acarinina interposita (245.68 mbsf), (13) ventral view, (14) edge view, (15) dorsal view. 16. Acarinina soldadoensis (275.25 mbsf). 17, 18. Acarinina triplex (264.35 mbsf), (17) ventral view, (18) edge view. 19, 20. Acarinina intermedia (278.90 mbsf), (19) ventral view, (20) edge view. 


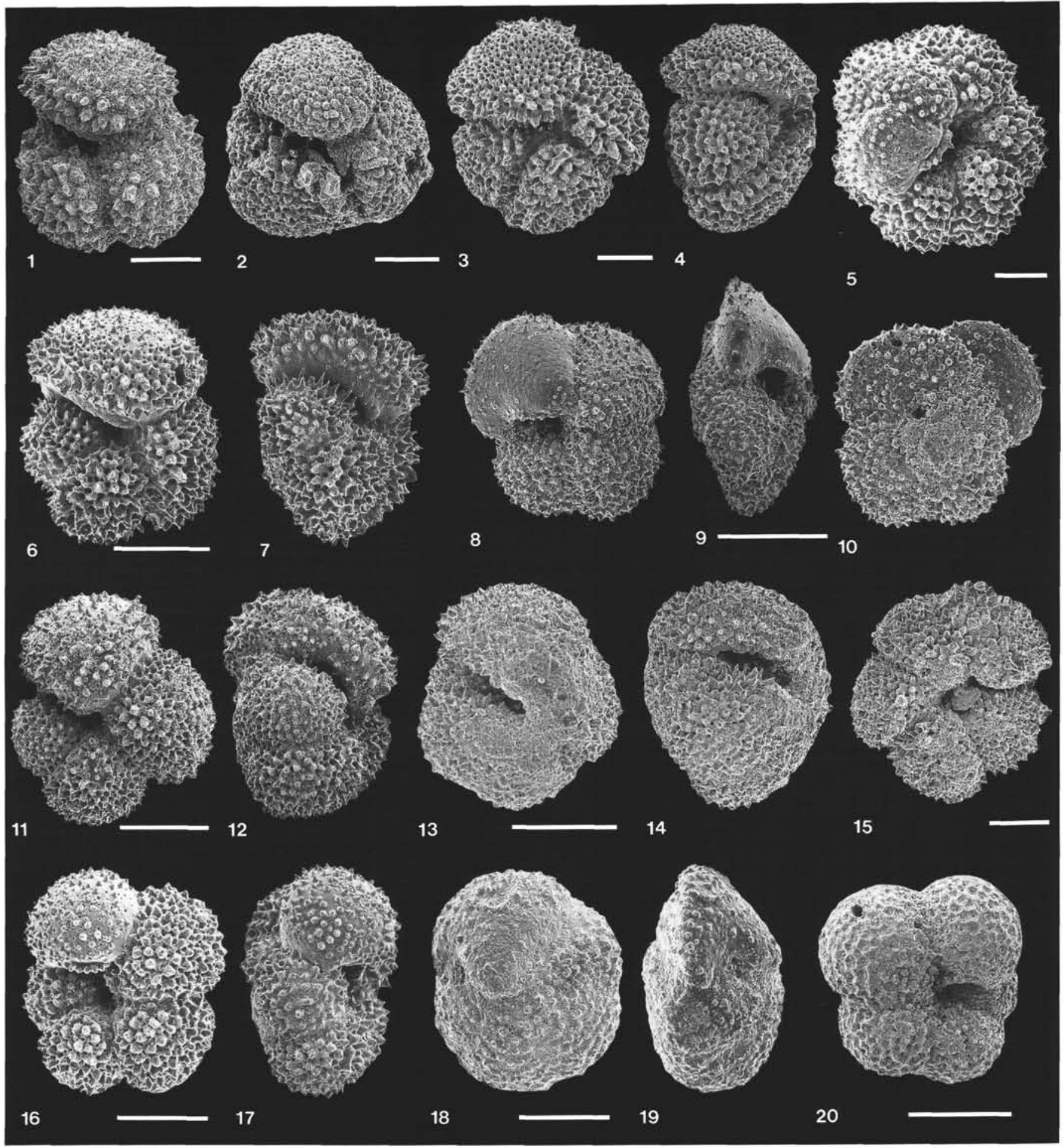

Plate 3. Late Paleocene-middle Eocene acarininid and igorinid foraminifers recovered from Holes 738B and 738C. Scale bars for all figures represent $100 \mu \mathrm{m}$. 1. Acarinina primitiva (126.70 mbsf). 2. Acarinina coalingensis (247.83 mbsf). 3, 4. Acarinina matthewsae (149.18 mbsf), (3) ventral view, (4) edge view. 5. Acarinina broedermanni (206.79 mbsf). 6, 7. Acarinina bullbrooki (142.02 mbsf), (6) ventral view, (7) edge view. 8-10. Acarinina cf. A. collactea (126.70 mbsf), (8) ventral view, (9) edge view, (10) dorsal view. 11, 12. Acarinina spinuloinflata (124.70 mbsf), (11) ventral view, (edge view). 13, 14. Acarinina nitida (245.68 mbsf), (13) ventral view, (14) edge view. 15. Acarinina cuneicamerata (206.79 mbsf). 16, 17. Acarinina collactea (131.88 mbsf), (16) ventral view, (17) edge view. 18, 19. Igorina pusilla (302.83 mbsf), (18) ventral view, (19) edge view. 20. Igorina spiralis (338.50 mbsf). 

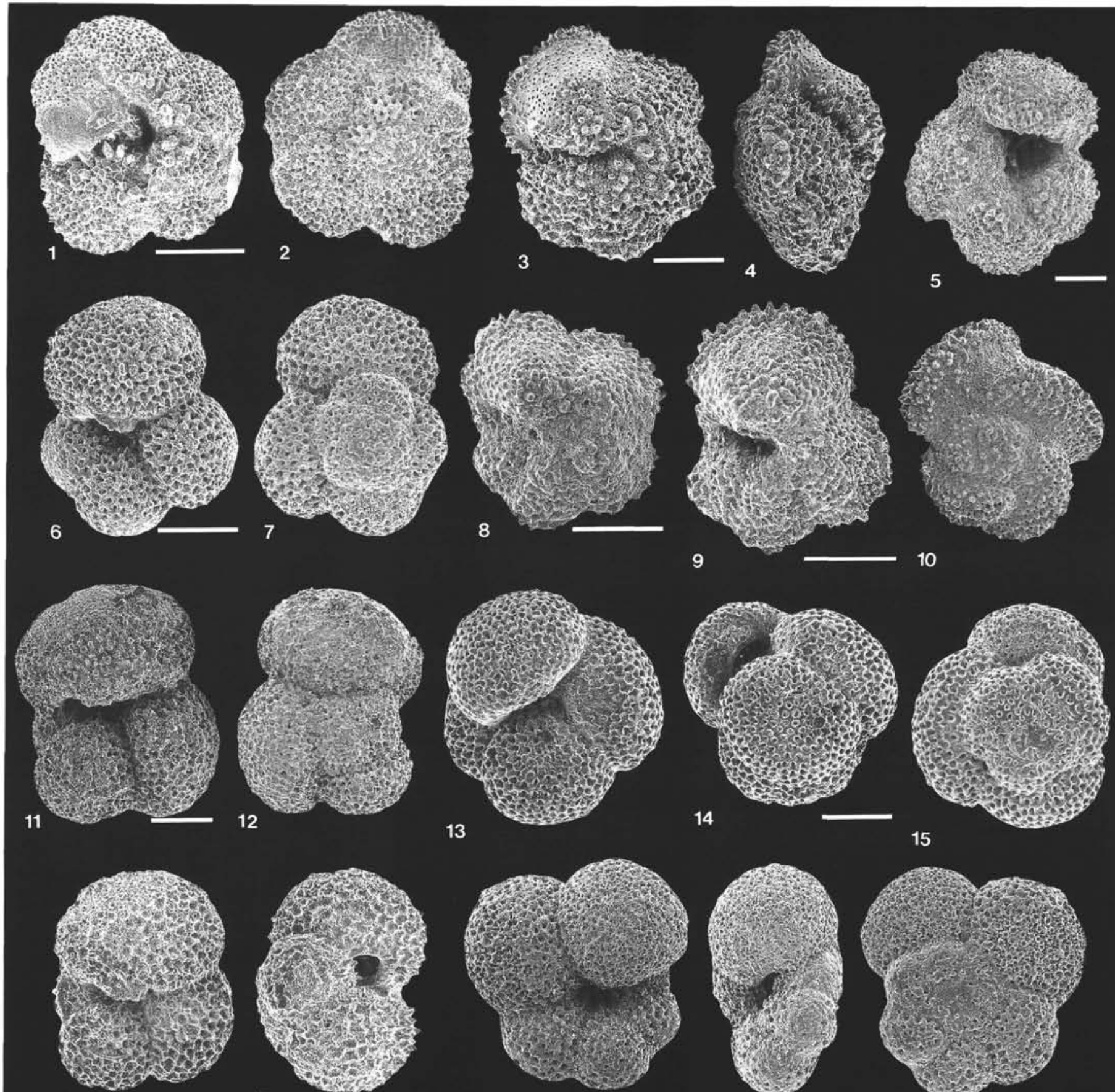

16
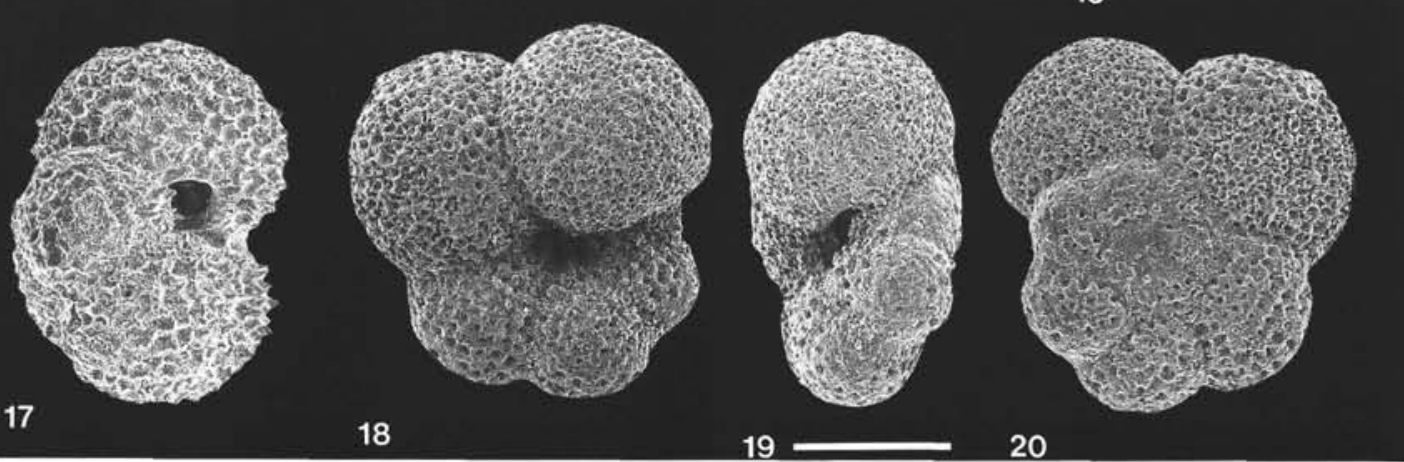

Plate 4. Late Paleocene-middle Eocene morozovellid and subbotinid foraminifers recovered from Holes 738B and 738C. Scale bars for all figures represent $100 \mu \mathrm{m}$. 1, 2. Acarinina apanthesma (332.15 mbsf), (1) ventral view, (2) dorsal view. 3, 4. Morozovella spinulosa (132.37 mbsf), (3) ventral view, (4) edge view. 5, 10. Morozovella $\mathrm{cf}$. M. quetra (126.70 mbsf), (5) ventral view, (10) dorsal view. 6, 7. Subbotina varianta (286.05 mbsf), (6) ventral view, (7) dorsal view. 8. Morozovella gracilis (277.78 mbsf). 9. Morozovella subbotinae (277.78 mbsf). 11, 12. Subbotina velascoensis (284.55 mbsf), (11) ventral view, (12) dorsal view. 13-15. Guembelitrioides sp. (274.75 mbsf), (13) ventral view, (14) edge view, (15) dorsal view. 16, 17. Subbotina patagonica (206.79 mbsf), (16) ventral view, (17) edge view. 18-20. "Planorotalites" reissi (236.04 mbsf), (18) ventral view, (19) edge view, (20) dorsal view. 

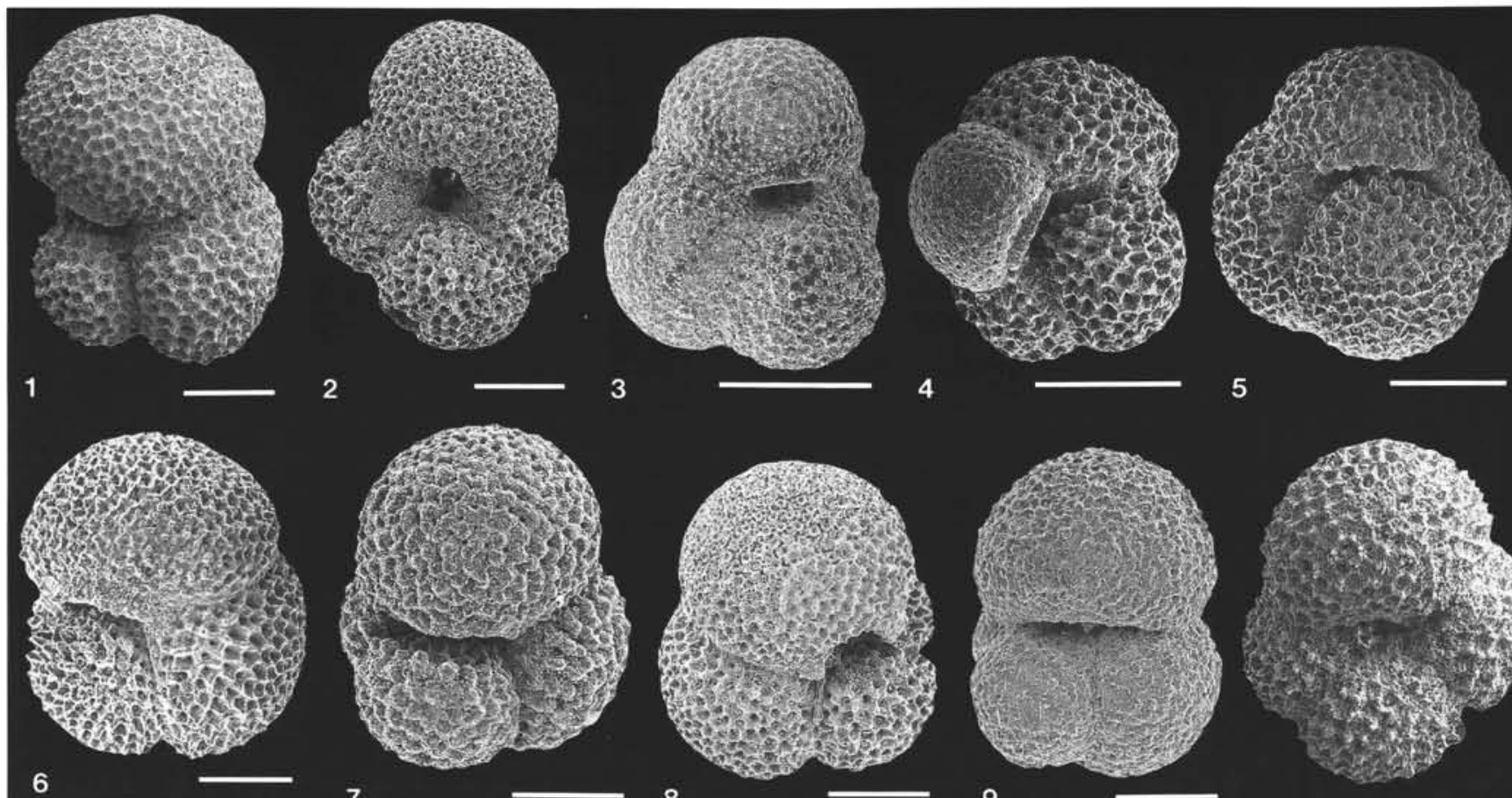

7
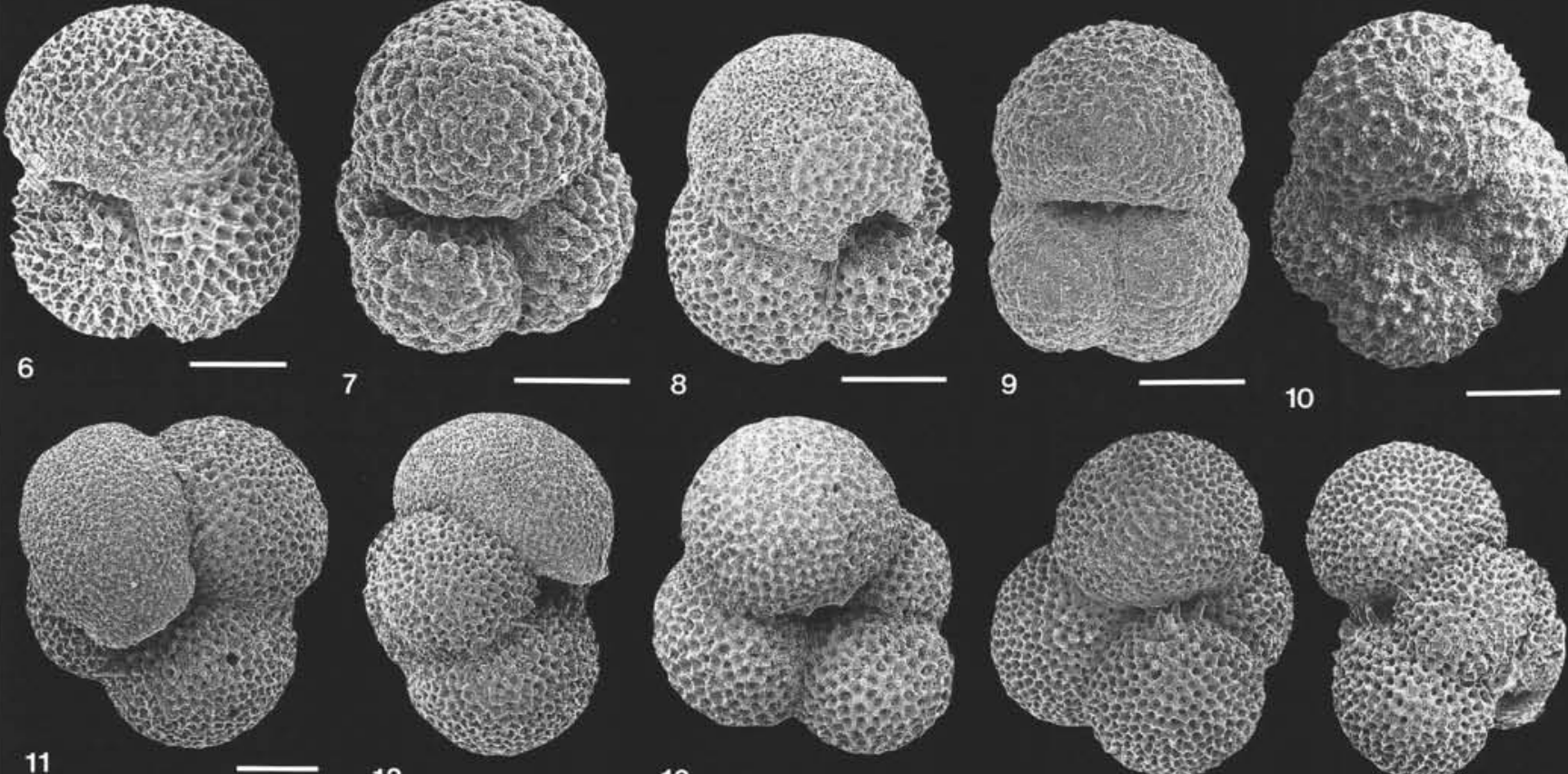

9

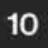

18
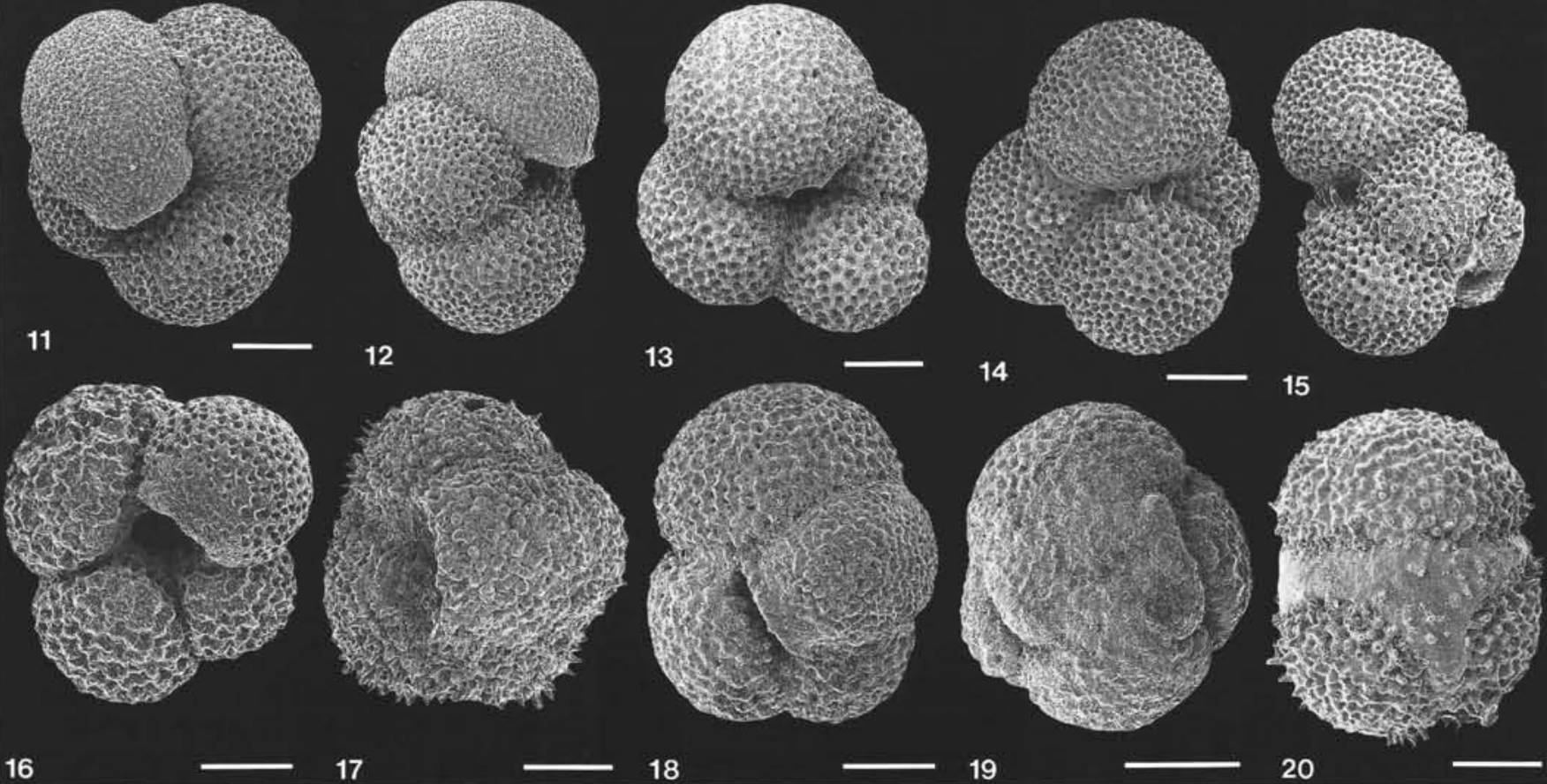

Plate 5. Eocene-Oligocene subbotinid, globigerinid, and catapsydracid planktonic foraminifers from Sites 738 and 744 . Sub-bottom depths are presented for Site 738 specimens and sample numbers are given for Site 744 specimens. Scale bars for all figures represent $100 \mu \mathrm{m}$. 1. Subbotina linaperta s.s. (61.00 mbsf). 2. Subbotina pseudoeocaena (206.79 mbsf). 3. Subbotina triangularis (126.70 mbsf). 4. Subbotina hardingae (206.79 mbsf). 5. Subbotina angiporoides $(23.90 \mathrm{mbsf})$. 6. Subbotina utilisindex $(23.90 \mathrm{mbsf})$. 7. Globigerina euapertura $(119-744 \mathrm{~A}-15 \mathrm{H}-5,95-100 \mathrm{~cm})$. 8. Subbotina brevis $(22.43 \mathrm{mbsf})$. 9. Globoturborotalita brazieri $(119-744 \mathrm{~A}-12 \mathrm{H}-3,95-100 \mathrm{~cm}) .10$. Globigerina leroyi $(50.99 \mathrm{mbsf}) .11$, 12. Subbotina pseudovenezuelana (119-744A-15H-5, 95-100 cm), (11) ventral view, (12) edge view. 13. Subbotina eocaena (50.99 mbsf). 14, 15. Subbotina gortanii (37.90 mbsf), (14) ventral view, (15) edge view. 16. Globoturborotalita labiacrassata (119-744A-13H-5, 95-100 cm). 17. Catapsydrax echinatus (Sample 119-744-15H-CC). 18. Catapsydrax unicavus (42.00 mbsf). 19. Catapsydrax dissimilis (Sample 119-744A-10H-CC). 20. Catapsydrax echinatus (Sample 119-744A-15H-CC). 


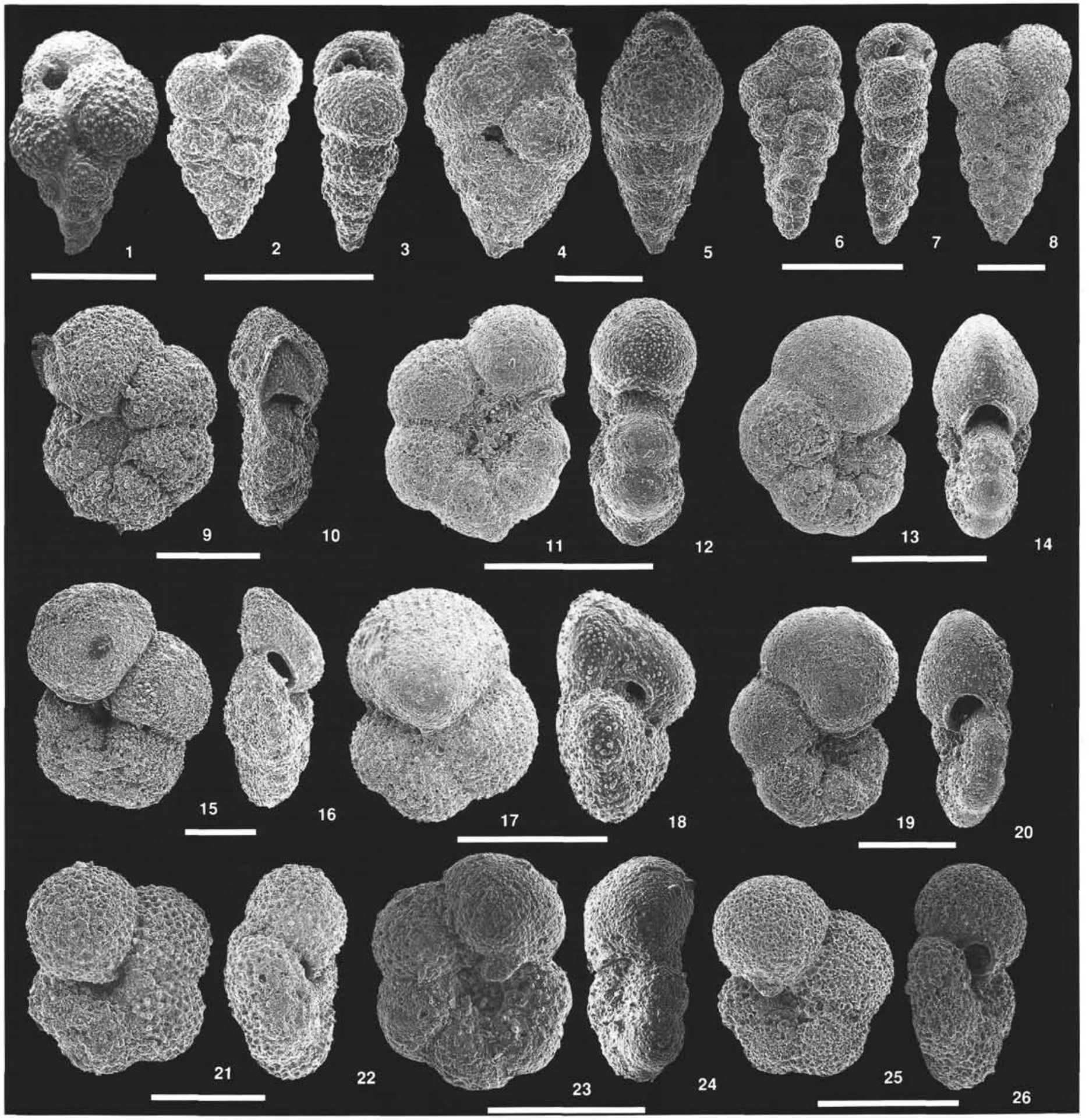

Plate 6. Eocene-Oligocene heterohelicid, pseudohastigerinid, planorotalitid, and praetenuitellid planktonic foraminifers from Site 738. Scale bars for all figures represent $100 \mu \mathrm{m}$. 1. Guembelitria columbiana (143.89 mbsf). 2, 3. Chiloguembelina crinita (236.04 mbsf), (2) lateral view, (3) edge view. 4, 5. Chiloguembelina wilcoxensis ( $264.35 \mathrm{mbsf})$, (4) lateral view, (5) edge view. 6, 7. Chiloguembelina morsei (264.35 mbsf), lateral view, (7) edge view. 8. Chiloguembelina cubensis (32.50 mbsf). 9, 10. Psuedohastigerina wilcoxensis (264.35), (9) ventral view, (10) edge view. 11, 12. Pseudohastigerina sp. (153.57 mbsf), (11) ventral view, (12) edge view. 13, 14. Pseudohastigerina micra (126.70 mbsf), (13) ventral view, (14) edge view. 15, 16. Planorotalites planoconicus (265.01 mbsf), (15) umbilical view, (16) edge view. 17, 18. Planorotalites australiformis (196.93 mbsf), (17) ventral view, (18) edge view. 19, 20. Planorotalites chapmani (265.01 mbsf), (19) ventral view, (20) edge view. 21, 22. "Planorotalites" imitatus (338.50 mbsf), (21) ventral view, (22) edge view. 23, 24. Planorotalites sp. 2 (264.35 mbsf), (23) ventral view, (24) edge view. 25, 26. Praetenuitella sp. 1 (142.02 mbsf), (25) ventral view, (26) edge view. 


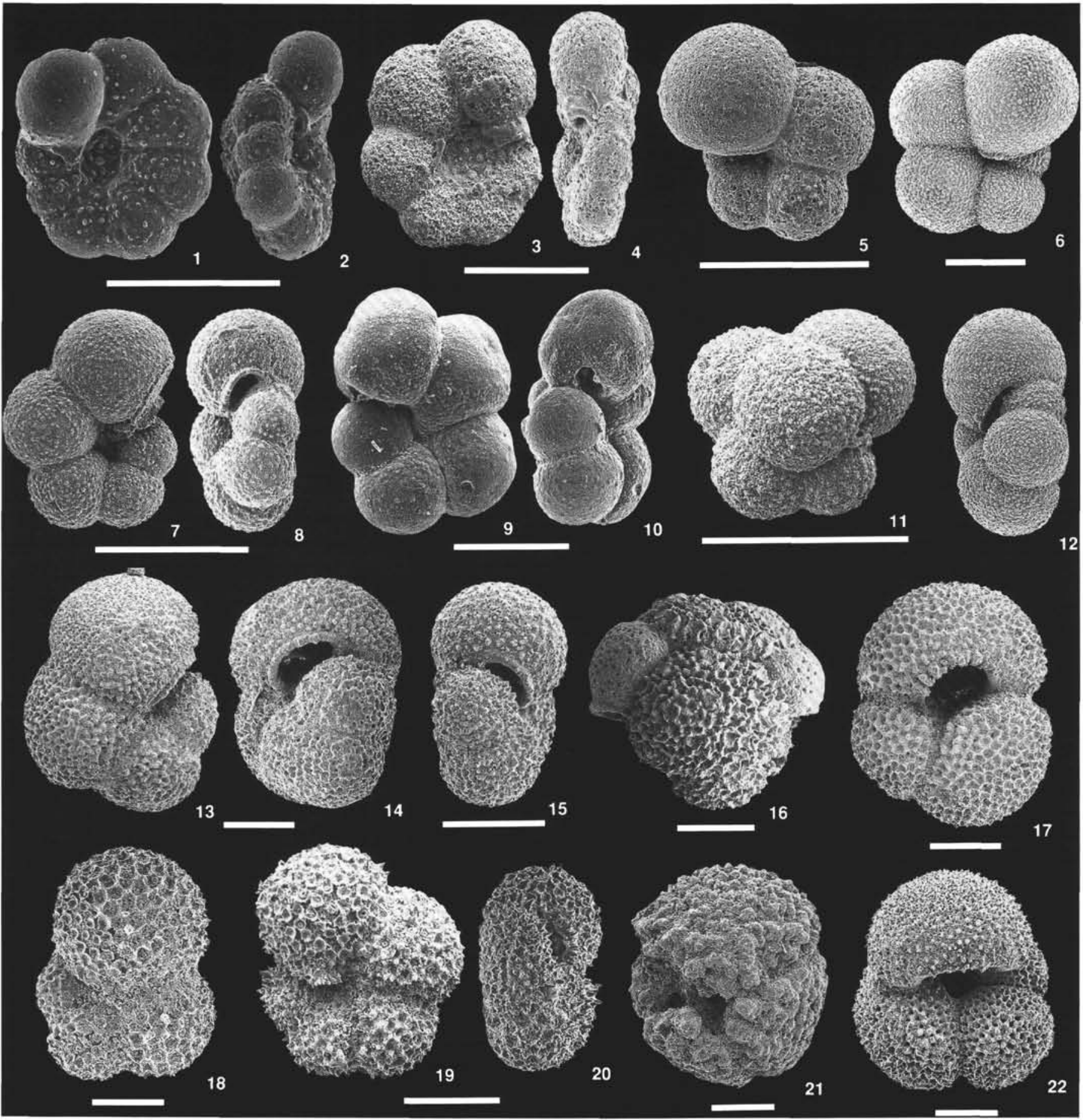

Plate 7. Late Eocene-Oligocene planktonic foraminifers from Sites 738 and 744 . Sub-bottom depths are presented for Site 738 specimens and sample numbers are given for Site 744 specimens. Scale bars for all figures represent $100 \mu \mathrm{m}$. 1, 2. Praetenuitella sp. 3 (66.40 mbsf), (1) ventral view, (2) edge view. 3, 4. Praetenuitella sp. 2 ( $44.40 \mathrm{mbsf})$, (3) ventral view, (4) edge view. 5. Tenuitella munda ( $40.90 \mathrm{mbsf})$. 6, 12. Tenuitella angustiumbilicata (119-744A-15H-5, 95-100 cm), (6) ventral view, (12) edge view. 7, 8. Tenuitella gemma (744A-17H-1, 28-33 cm), (7) ventral view, (8) edge view. 9, 10. Praetenuitella insolita (40.90 mbsf), (9) ventral view, (10) edge view. 11. Cassigerinelloita amekiensis (196.93 mbsf). 13, 14. Paragloborotalia pseudocontinuosa (50.99 mbsf), (13) ventral view, (14) edge view. 15. Edge view of Paraturborotalia nana (47.40 mbsf). 16. Globigerinatheka barri $(36.40 \mathrm{mbsf})$. 17. Globigerinatheka index (42.00 mbsf). 18. Globorotaloides suteri $(61.00 \mathrm{mbsf})$. 19, 20. Globorotaloides cf. G. testarugosa (23.90 mbsf), (19) ventral view (20) edge view. 21. Muricoglobigerina senni (126.70 mbsf). 22. Globigerinatheka index (131.88 mbsf). 